\title{
Development and Testing of Cool-Season Grass Species, Varieties and Hybrids for Biomass Feedstock Production in Western North America
}

\author{
Steven R. Larson ${ }^{1}$ * , Calvin H. Pearson ${ }^{2}$, Kevin B. Jensen ${ }^{1}$, Thomas A. Jones ${ }^{1}$, Ivan W. Mott ${ }^{1}$, \\ Matthew D. Robbins ${ }^{1}$, Jack E. Staub ${ }^{1}$ and Blair L. Waldron ${ }^{1}$ \\ 1 USDA-ARS, Forage and Range Research, Utah State University, Logan, UT 84322, USA; \\ Kevin.Jensen@ars.usda.gov (K.B.J.); Thomas.Jones@ars.usda.gov (T.A.J.); Ivan.Mott@ars.usda.gov (I.W.M.); \\ Matthew.Robbins@ars.usda.gov (M.D.R.); Jack.Staub@ars.usda.gov (J.E.S.); \\ Blair.Waldron@ars.usda.gov (B.L.W.) \\ 2 Agriculture Experiment Station, Department of Soil and Crop Sciences, Colorado State University, Fruita, \\ CO 81521, USA; Calvin.Pearson@colostate.edu \\ * Correspondence: Steve.Larson@ars.usda.gov; Tel.: +1-436-5-797-1703
}

Academic Editors: John W. Forster and Smith Kevin F. Smith

Received: 29 September 2016; Accepted: 14 December 2016; Published: 1 January 2017

\begin{abstract}
Breeding of native cool-season grasses has the potential to improve forage production and expand the range of bioenergy feedstocks throughout western North America. Basin wildrye (Leymus cinereus) and creeping wildrye (Leymus triticoides) rank among the tallest and most rhizomatous grasses of this region, respectively. The objectives of this study were to develop interspecific creeping wildrye $(\mathrm{CWR}) \times$ basin wildrye $(\mathrm{BWR})$ hybrids and evaluate their biomass yield relative to tetraploid 'Trailhead', octoploid 'Magnar' and interploidy-hybrid 'Continental' BWR cultivars in comparison with other perennial grasses across diverse single-harvest dryland range sites and a two-harvest irrigated production system. Two half-sib hybrid populations were produced by harvesting seed from the tetraploid self-incompatible Acc:641.T CWR genet, which was clonally propagated by rhizomes into isolated hybridization blocks with two tetraploid BWR pollen parents: Acc:636 and 'Trailhead'. Full-sib hybrid seed was also produced from a controlled cross of tetraploid 'Rio' CWR and 'Trailhead' BWR plants. In space-planted range plots, the 'Rio' CWR × 'Trailhead' BWR and Acc:641.T CWR $\times$ Acc:636 BWR hybrids displayed high-parent heterosis with 75\% and 36\% yield advantages, respectively, but the Acc:641.T CWR $\times$ 'Trailhead' BWR hybrid yielded significantly less than its BWR high-parent in this evaluation. Half-sib CWR $\times$ BWR hybrids of Acc:636 and 'Trailhead' both yielded as good as or better than available BWR cultivars, with yields similar to switchgrass (Panicum virgatum), in the irrigated sward plots. These results elucidate opportunity to harness genetic variation among native grass species for the development of forage and bioenergy feedstocks in western North America.
\end{abstract}

Keywords: arid ecosystems; cold-desert; high-elevation; interspecific hybrids; self-incompatibility

\section{Introduction}

Development of biofuel feedstocks in the United States has been focused on switchgrass (Panicum virgatum) as a model crop system in part because of its performance in herbaceous crop screening trials conducted across Alabama, Iowa, Indiana, New York, North Dakota, Ohio and Virginia; and also because decision makers recognized the strategic importance to demonstrate the feasibility of developing a cellulosic biofuel crop with limited funding [1-4]. Switchgrass is a warm-season rhizomatous perennial grass endemic to southeastern North America encompassing parts of Cuba, southeastern Canada, northeastern Mexico, and most the United States east of the 
Rocky Mountains [5] including all of the states where it was tested during the initial phase of biofuel feedstock screening in the United States [1-4]. However, with the exception of western North Dakota, located near the geographic center of North America, most of the western United States was excluded from the initial herbaceous crop screening process [1-4]. Studies have shown that cool-season perennial Triticeae grasses including crested wheatgrass (Agropyron desertorum), intermediate wheatgrass (Thinopyrum intermedium), mammoth wildrye (Leymus racemosus), tall wheatgrass (Thinopyrum ponticum), and native western wheatgrass (Pascopyrum smithii) may be useful for forage and bioenergy feedstock production across the prairie provinces of Canada and the central United States including Alberta, Kansas, Manitoba, North Dakota, Saskatchewan, and South Dakota [1,4,6-10]. These cool-season perennial Triticeae grasses are also well adapted to the high-elevation cold-desert Great Basin region of the western United States including large regions of Nevada and Utah [11-13]. Intermediate wheatgrass and tall wheatgrass produced substantially more biomass than warm-season grasses, including five varieties of switchgrass, in a five-harvest irrigated production system in northern Utah [11]. Basin wildrye (Leymus cinereus) performed relatively well in low-irrigation single-harvest management systems in the cold-desert environments of the Idaho, Nevada, and Utah [12,14], where this species is native. However, efforts to improve biomass productivity of these cool-season perennial grasses lag behind switchgrass or miscanthus.

The development and testing of intraspecific and interspecific hybrids has been a focal point of breeding and genetic research in bioenergy grasses [15], including switchgrass and miscanthus. One of the most productive forms of miscanthus (Miscanthus $\times$ giganteus) is a sterile hybrid between Miscanthus sacchriflorus and Miscanthus sinensis that is clonally propagated by rhizomes [1,16-19]. Some hybrids of $M$. sacchriflorus and M. sinensis display up to $30 \%-35 \% \mathrm{~F}_{1}$ high-parent heterosis without selection for specific combining ability [20], and there has been considerable effort to identify, develop, and test new miscanthus hybrids [19,21-24]. Switchgrass hybrids also show evidence of heterosis. Full-sib hybrid families, population hybrids, and advanced generation synthetic hybrid populations of upland and lowland switchgrass ecotypes showed evidence of mid-parent heterosis in spaced-plant plots [25] and high-parent heterosis in sward plots [26]. Extensive testing of reciprocal crosses within and between the upland and lowland ecotypes detected no evidence of high-parent heterosis and mid-parent heterosis was limited to a small fraction of the hybrids [27]. Nevertheless, the identification of complementary gene pools is expected to help produce useful hybrids and hybrid-derived populations for switchgrass biomass production $[5,28,29]$. As a native plant species, there is a wealth of regionally adapted genetic resources available for the development of switchgrass varieties and hybrids in North America $[1,5,29,30]$. Likewise, development and testing of native cool-season grasses has the potential to diversify cropping systems and expand the expected range of adaptation of bioenergy feedstocks throughout western North America.

Basin wildrye (BWR) is considered one of the largest and most conspicuous native bunchgrasses in western North America, with aerial stems in excess of $2 \mathrm{~m}$ [31] and a deep fibrous root system [12,32]. Although the native range of BWR is quite large, its distribution is restricted to sites where water and soil accumulate, which includes road sides and field margins [33]. Three genetically distinct races, including allotetraploid $(2 \mathrm{n}=4 x=28)$ and auto-duplicated octoploid $(2 \mathrm{n}=8 \mathrm{x}=56)$ cytotypes, have been identified and named based on their corresponding distributions across the Columbia, Rocky Mountain, and Great Basin ecogeographic regions [33]. The octoploid (8X) cytotypes have significantly larger leaves, longer culms, and greater crown circumference compared to tetraploid (4X) cytotypes, and there is evidence of climatic adaptations within BWR [34]. However, it is not known how these differences related to biomass productivity under cultivation. The two standard BWR varieties—octoploid (8X) 'Magnar' and tetraploid (4X) 'Trailhead'—were collected directly from wild natural populations in southeastern British Columbia (Columbia race) and southcentral Montana (Rocky Mountain race), respectively [33], without subsequent selection. A new synthetic BWR variety, 'Continental', was selected from a hybrid population of chromosome-doubled ( $4 \mathrm{X}+4 \mathrm{X})$ 'Trailhead' and $8 \mathrm{X}$ 'Magnar' [35]. 'Continental' was released based on its superior stand establishment in range 
seeding evaluations [35], but the biomass-related traits of 'Continental' have not been compared to 'Trailhead', 'Magnar', or any other grass. Although BWR shows potentially useful biomass yields in a single-harvest management systems [12,14], none of the BWR cultivars were bred for biomass yield and they may lack the defoliation tolerance needed for more intensive multiple-harvest production systems [14].

Creeping wildrye (Leymus triticoides) is closely related to BWR and has a similar range of distribution throughout western North America, but it is usually found in different habitats such as saline meadows and harsh alkaline sites in [33]. Creeping wildrye (CWR) is also different from BWR in that it has extensive rhizomes, typically grows much shorter than BWR, and it had significantly lower biomass yield, by about $50 \%$, in comparisons with BWR [14,31]. The only available CWR cultivar, 'Rio', was collected from a natural population in Kings Valley of California [36] and has been evaluated as a forage and biomass crop in the western San Joaquin Valley using saline-sodic drainage water for irrigation [37,38].

Interspecific hybrids of CWR and BWR have been developed and tested for biomass yield and other agronomic traits $[14,31]$. In a single-harvest management system, two CWR $\times$ BWR single-cross hybrid genets showed indications of mid-parent heterosis for dry matter yield (DMY), with both hybrids showing substantially better yields than the lower-yielding CWR parent, and one of the single-cross hybrid genets showed significantly $(p<0.001)$ greater yields than the higher-yield BWR parent [14]. It was also postulated that increased rhizomatousness in the CWR $\times$ BWR hybrids may provide a mechanism of defoliation tolerance and regrowth not present in BWR [14,39], which may in turn facilitate management in multiple-harvest production systems. However, these previous studies $[14,39]$ were based on evaluations of clonal propagules from two single-cross hybrid genets. The difficulty of controlling pollination and producing substantial quantities of hybrid seed has limited the testing of CWR $\times$ BWR hybrids on the field-scale level [14], which has also been a challenge with switchgrass and other allogamous perennial grasses [26]. Thus, for this study, we have proposed a strategy to produce larger volumes of hybrid seed for different CWR $\times$ BWR hybrids by growing rhizome propagules from one self-incompatible CWR genet, Acc:641.T, in isolated field hybridization plots with different varieties or natural populations of BWR as the only available pollen source. Using this approach, we anticipated several possible outcomes: (1) distinct half-sib hybrid seed populations resulting from crosses of Acc:641.T CWR pollinated by different BWR populations; (2) no seed set due to the lack of compatible pollen; and (3) seeds resulting from self-fertilization of the Acc:641.T CWR genet.

The overall purpose of the research reported herein was to develop and test BWR and CWR $\times$ BWR hybrids for efficient biomass feedstock production in western North America. This study addresses several questions:

- Is it possible to utilize the gametophytic self-incompatibility mechanism of perennial grasses combined with the highly rhizomatous nature of CWR to mass produce half-sib hybrid seed for different 4 X CWR $\times 4$ X BWR or 4 X CWR $\times 8 X$ BWR crosses on a field scale level?

- How do the relative biomass yields of CWR $\times$ BWR half-sib hybrids and higher-yielding BWR parent varieties compare to relative yields of previously tested CWR $\times$ BWR hybrid genets and their BWR parent varieties [14], in single-harvest dryland range production systems?

- What is the relative performance of CWR $\times$ BWR hybrids, interploidy BWR hybrid, standard BWR varieties, and other bioenergy candidate species in terms of DMY in a two-harvest irrigated production system of western North America?

- Do the CWR $\times$ BWR hybrids show evidence of biomass heterosis?

Specific experimental objectives that were formulated to address these questions were to (1) compare the yield, average seed size, and percent germination of seed harvested from one $4 \mathrm{X}$ CWR genet (Acc:641.T) grown in combination with different $4 \mathrm{X}$ or 8X BWR populations in isolated hybridization plots; (2) examine the genetic identity of seed harvested from the $4 \mathrm{X}$ Acc:641.T 
CWR genet, in different hybridization plots, relative to CWR and BWR parental genotypes, using DNA markers; (3) compare biomass accumulation potential of half-sib CWR $\times$ BWR hybrids and the interploidy BWR hybrid to the high-parent BWR reference populations in dryland range environments, and; (4) compare early-season, late-season, and average yearly biomass yields of half-sib CWR $\times$ BWR hybrids, the interploidy BWR hybrid, two standard BWR varieties, intermediate wheatgrass, switchgrass, and tall wheatgrass in a two-harvest irrigated management system designed for efficient biomass production in this region.

\section{Results}

\subsection{Yield and Quality of Half-Sib Hybrid Seed Production}

Yield, average seed weights, and percent germination of seed harvested from hybridization plots were significantly influenced $(p<0.001)$ by the presence of different BWR pollen populations (Table 1 ). Seed yield and average seed weights also showed significant variation $(p<0.001)$ over years. Seed yield in the second year was significantly higher $(p<0.05)$ than other years (Table 1$)$ but seed weights were significantly greater $(p<0.001)$ in the first year compared to other years (results not shown). Seed yields in the fourth year were significantly lower than the second year $(p<0.001)$ or third year $(p<0.05)$ and seed weights in the fourth year were significantly lower than all other years $(p<0.001)$. The average seed yields in hybridization plots containing 4 X BWR pollen parents $\left(5.9 \mathrm{~g} \cdot \mathrm{m}^{-2}\right)$ was significantly greater $(p<0.001)$ than the average seed yields in hybridization plots containing 4 X BWR pollen parents $\left(1.0 \mathrm{~g} \cdot \mathrm{m}^{-2}\right)$. The average seed weights in hybridization plots containing 4 X BWR pollen parents $(2.68 \mathrm{mg})$ was significantly greater $(p<0.001)$ than the average seed yields in hybridization plots containing $4 X$ BWR pollen parents $(1.74 \mathrm{mg})$. Finally, the percent germination in hybridization plots containing 4 X BWR pollen parents $(56.3 \%)$ was significantly greater $(p<0.001)$ than the average seed yields in hybridization plots containing $4 \mathrm{X}$ BWR pollen parents $(11.0 \%)$.

Table 1. Yield, average seed weight, and percent germination of seed harvested from the tetraploid (4X) Acc:641.T creeping wildrye genet grown in hybridization plots containing octoploid (8X) or tetraploid (4X) basin wildrye (BWR) pollen-parent populations. Significant differences among groups of entry means are indicated by lettered ranks, within table columns, based on least significant differences $(p<0.05)$.

\begin{tabular}{|c|c|c|c|c|c|c|c|}
\hline $\begin{array}{l}\text { BWR Pollen-Parent } \\
\text { Population }\end{array}$ & $\begin{array}{c}\text { Year } 1 \\
\text { Yield } \\
\left(\mathrm{g} \cdot \mathrm{m}^{-2}\right)\end{array}$ & $\begin{array}{c}\text { Year } 2 \\
\text { Yield } \\
\left(\mathrm{g} \cdot \mathrm{m}^{-2}\right)\end{array}$ & $\begin{array}{c}\text { Year } 3 \\
\text { Yield } \\
\left(\mathrm{g} \cdot \mathrm{m}^{-2}\right)\end{array}$ & $\begin{array}{c}\text { Year } 4 \\
\text { Yield } \\
\left(\mathrm{g} \cdot \mathrm{m}^{-2}\right)\end{array}$ & $\begin{array}{c}\text { Avg. } \\
\text { Yield } \\
\left(\mathrm{g} \cdot \mathrm{m}^{-2}\right)\end{array}$ & $\begin{array}{c}\text { Seed } \\
\text { Weight } \\
\text { (mg) }\end{array}$ & $\begin{array}{c}\text { Percent } \\
\text { Germination }\end{array}$ \\
\hline 4X Acc:636 BWR & $3.8 \mathrm{a}$ & $10.2 \mathrm{a}$ & $4.5 \mathrm{~b}$ & $1.9 \mathrm{ab}$ & $5.1 \mathrm{~b}$ & $2.70 \mathrm{a}$ & $54.1 \mathrm{a}$ \\
\hline $8 \mathrm{X}$ ‘Continental’ BWR & $0.6 \mathrm{~b}$ & $1.8 \mathrm{~b}$ & $1.0 \mathrm{c}$ & $0.2 \mathrm{c}$ & $0.9 \mathrm{c}$ & $1.72 \mathrm{~b}$ & $12.5 \mathrm{~b}$ \\
\hline 8X 'Magnar' BWR & $0.4 \mathrm{~b}$ & $2.1 \mathrm{~b}$ & $1.3 \mathrm{c}$ & $0.5 \mathrm{bc}$ & $1.1 \mathrm{c}$ & $1.75 \mathrm{~b}$ & $9.6 \mathrm{~b}$ \\
\hline 4X 'Trailhead' BWR & $3.7 \mathrm{a}$ & $12.1 \mathrm{a}$ & $7.7 \mathrm{a}$ & $3.1 \mathrm{a}$ & $6.6 \mathrm{a}$ & $2.67 \mathrm{a}$ & $58.5 \mathrm{a}$ \\
\hline Standard error & 0.6 & 2.5 & 0.6 & 0.5 & 0.6 & 0.05 & 2.8 \\
\hline Average & 2.1 & 6.6 & 3.6 & 1.4 & 3.4 & 2.21 & 33.7 \\
\hline
\end{tabular}

\subsection{Genetic Identity and Genetic Diversity of Seed Harvested from $C W R \times B W R$ Hybridization Plots}

Principle coordinates analysis of DNA profiles from individual plants elucidated genetic diversity within and between three major groups comprised of CWR, BWR, and apparent half-sib hybrids of CWR and BWR (Figure 1). Moreover, genetically distinct subgroups corresponding to the 4X Acc:636, $4 X$ 'Trailhead', and $8 X$ 'Magnar' populations were also detectable within the highly-diverse BWR group (Figure 1). The 8X 'Continental' BWR interploidy hybrid population showed considerable overlap with its $8 X$ 'Magnar' BWR parent population, but it did not overlap with its other 4X 'Trailhead' BWR parent population (Figure 1). Most of the progeny sampled from the hybridization plots appeared to be hybrids of CWR and BWR, similar to previously described TC1 and TC2 single-cross hybrid genets of the 4X Acc:641 CWR $\times 4$ X Acc:636 BWR cross (Figure 1). In fact, the TC1 and TC2 hybrids 
were indistinguishable from progeny sampled from hybridization plots containing 4X Acc:636 BWR (Figure 1), which all have a very similar genetic background except that the TC1 and TC2 single-cross hybrids originated from 4X Acc:641 CWR plants that were not genetically identical to the 4X Acc:641.T CWR genet.

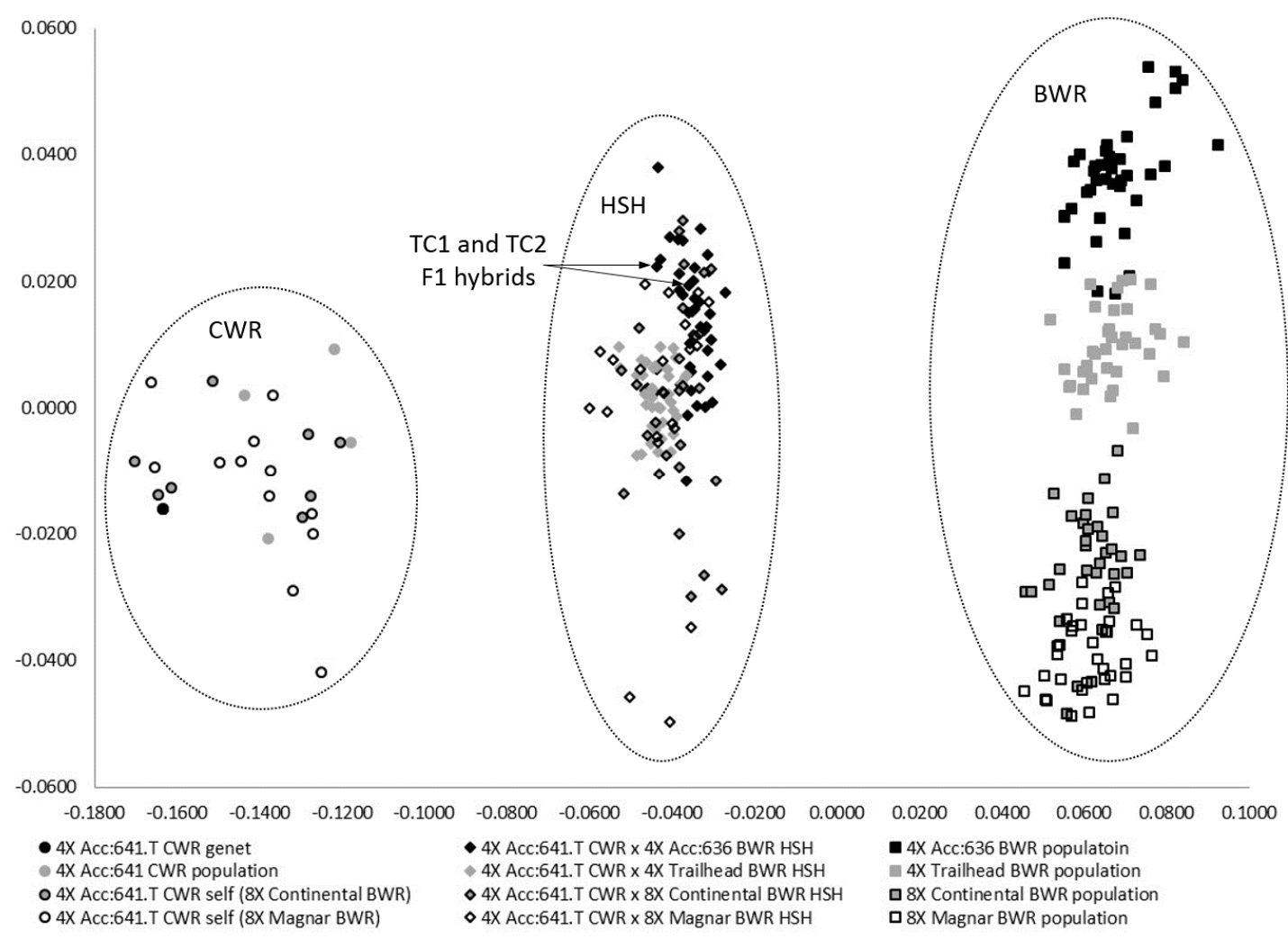

Figure 1. Principle coordinates analysis of genetic similarity coefficients among DNA genotypes from 314 individual plants of creeping wildrye (CWR), basin wildrye (BWR), and half-sib hybrid (HSH) populations harvested from the 4X Acc:641.T CWR genet in hybridization plots containing tetraploid (4X) or octoploid (8X) pollen-parent populations of 4X Acc:636 BWR, 4X 'Trailhead' BWR, 8X 'Continental' BWR, and 8X 'Magnar' BWR. Population identifiers include presumed self-progeny of the 4X Acc:641.T CWR genet (from hybridization plots containing 8X 'Continental' BWR or 8X 'Magnar' BWR). The identity of two 4x Acc:641 CWR $\times 4$ X Acc:636 BWR single-cross hybrids, TC1 and TC2, are also identified.

Not all of the progeny harvested from hybridization plots containing 8X BWR pollen sources appeared to be CWR $\times$ BWR hybrids. Eight of the 33 progeny sampled from hybridization plots containing the $8 \mathrm{X}$ 'Continental' BWR pollen source grouped with other 4X Acc:641 CWR plants, indicating that approximately $24 \%$ of these progeny resulted from self-pollination of the $4 \mathrm{X}$ Acc: 641 .T CWR genet (Figure 1). Likewise, 12 of the 38 progeny sampled from hybridization plots containing the 8X 'Magnar' BWR pollen source grouped with other 4X Acc:641 CWR plants, indicating that approximately $32 \%$ of these progeny resulted from self-pollination of the 4X Acc:641.T CWR genet (Figure 1). All of the remaining progeny sampled from hybridization plots containing $4 \mathrm{X}$ or 8X BWR pollen parents were CWR $\times$ BWR hybrids, but many of these apparent hybrids did not separate into genetically distinct groups corresponding to the BWR pollen parents (Figure 1).

Bayesian cluster analysis (Figure 2) provided further insights into the ancestry of hybrid progeny. Four nearly-pure ancestry groups corresponding to 4X Acc:641 CWR, 4X Acc:636 BWR, 4X 'Trailhead' BWR, and 8X 'Magnar' were identified using an a priori model of $K=4$ Bayesian groups (Figure 2). As might be expected, plant samples from the $8 X$ 'Continental' interploidy BWR hybrid showed mixed 
ancestry coefficients ranging from about 0.25 to 0.75 'Trailhead' BWR and 0.75 to 0.25 'Magnar' BWR. As expected, all of the other progeny sampled from the 4X Acc:641.T CWR genet in hybridization plots containing BWR pollen sources, had nearly pure CWR ancestry or mixed ancestry coefficients of about 0.65 CWR and 0.35 BWR (Figure 2). All of the progeny sampled from hybridization plots containing the 4 X 'Trailhead' BWR pollen source appeared to be half-sib hybrids of 4 X Acc:641.T CWR genet $\times 4 X$ 'Trailhead' BWR (Figure 2). Likewise, most of the progeny sampled from hybridization plots containing the 4X Acc636 BWR pollen source appeared to be half-sib hybrids of 4X Acc:641.T CWR genet $\times 4 \mathrm{X}$ Acc636 BWR except that a few (at least six) appeared to be half-sib hybrids of 4X Acc:641.T CWR genet $\times 4 X$ 'Trailhead' BWR (Figure 2). Conversely, most of the progeny sampled from hybridization plots containing 8X BWR pollen sources, 'Magnar' or 'Continental', appeared to be half-sib hybrids of 4X BWR (either 'Trailhead' or Acc:636) or self-progeny of the 4X Acc:641.T CWR genet (Figure 2). Only three progeny from hybridization plots containing $8 \mathrm{X}$ 'Magnar' BWR as the pollen source actually contain 'Magnar' ancestry (Figure 2). Likewise, only three of the sampled progeny from hybridization plots containing $8 \mathrm{X}$ 'Continental' BWR as the pollen source actually contained portions of $4 \mathrm{X}$ Acc:641 CWR, 'Trailhead' BWR, and 'Magnar' ancestry expected from a "three-way hybrid" of the 4X Acc:641.T CWR genet and the $8 X$ 'Continental' interploidy BWR hybrid (Figure 2). Interestingly, most of the apparent hybrids of 4X Acc:641.T CWR genet $\times$ 8X BWR or self-pollinated 4X Acc:641.T CWR progeny occurred in the second evaluation year.

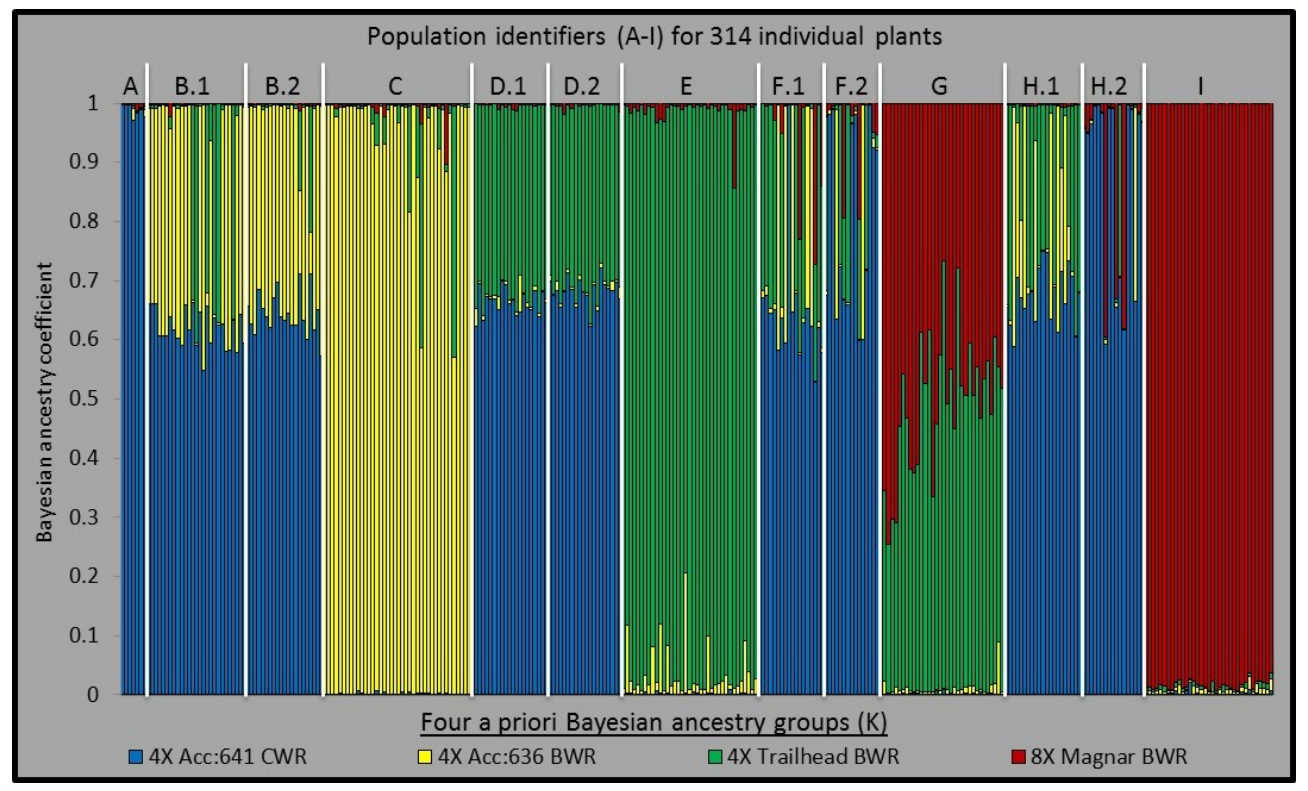

Figure 2. Bayesian cluster analysis of DNA genotypes from 314 individual plants of creeping wildrye (CWR), basin wildrye (BWR), and half-sib hybrid (HSH) populations harvested from the 4X Acc:641.T CWR genet in hybridization plots (HPs) containing tetraploid (4X) or octoploid (8X) pollen-parent populations of $4 \mathrm{X}$ Acc:636 BWR, 4X 'Trailhead' BWR, 8X 'Continental' BWR, and 8X 'Magnar' BWR. Population identifiers include (A) 4X Acc:641 CWR (including the 4X Acc:641.T CWR genet); (B) progeny of the 4X Acc:641.T CWR genet in HPs containing 4X Acc:646 BWR harvested in years 1 and 2; (C) 4X Acc:646 BWR; (D) progeny of the 4X Acc:641.T CWR genet in HPs containing 4X 'Trailhead' BWR harvested in years 1 and 2; (E) 4X 'Trailhead' BWR; (F) progeny of the 4X Acc:641.T CWR genet in HPs containing 8X 'Continental' BWR harvested in years 1 and 2; (G) 8X 'Continental' BWR; (H) progeny of the 4X Acc:641.T CWR genet in HPs containing 8X 'Magnar' BWR harvested in years 1 and 2; and (I) 8X 'Magnar' BWR.

The average genetic similarity coefficients $(\mathrm{S} \pm \mathrm{SE})$ varied from lowest to highest within populations of 4 X 'Trailhead' BWR $(0.641 \pm 0.005), 8 X$ ‘Continental' BWR $(0.676 \pm 0.005), 8 X$ 'Magnar' 
BWR $(0.707 \pm 0.006), 4$ X Acc:636 BWR $(0.710 \pm 0.005), 4 X$ Acc:641.T CWR $\times 4$ X 'Trailhead' BWR half-sib hybrid $(0.732 \pm 0.004), 4 X$ Acc:641.T CWR $\times 4$ X Acc:636 BWR half-sib hybrid $(0.742 \pm 0.004)$, and $4 \mathrm{X}$ Acc:641.T CWR $(0.746 \pm 0.012)$. The average genetic similarity coefficients within the two half-sib hybrid families were both significantly higher $(p<0.001)$ than their respective BWR pollen-parent populations. The average genetic similarity coefficient with the $8 \mathrm{X}$ 'Continental' BWR synthetic interploidy hybrid was significantly $(p<0.001)$ higher than its $4 X$ 'Trailhead' BWR parent and significantly $(p<0.001)$ lower than its 8X 'Magnar' BWR parent.

\subsection{Biomass Yields in Dryland Range Environments}

Dry matter yield of two half-sib hybrid populations was evaluated relative to four BWR reference populations in spaced-plant plots over two years and two dryland range environments: Providence and Tintic (Table S1). A full-sib hybrid population of 4X 'Rio' CWR $\times 4 \mathrm{X}$ 'Trailhead' BWR was also evaluated at the Providence site (Table 2) but there was insufficient seed to test this hybrid population at Tintic or any of the other sites. Variation in DMY was significantly influenced $(p<0.001)$ by main effects of population, location, and year. There was a significant interaction of year $\times$ location $(p<0.001)$, but there were no significant interactions of population $\times$ year or population $\times$ location. Values of DMY for each population were compared by location, in part because the full-sib hybrid population was not planted at the Tintic location (Table 2). The 4 X 'Rio' CWR $\times 4 X$ 'Trailhead' BWR full-sib hybrid population showed significantly $(p<0.05)$ greater DMY, compared to any other BWR or $\mathrm{CWR} \times \mathrm{BWR}$ population, at the Providence location (Table 2), which was true in the first and second year. The 4X Acc:641.T CWR $\times$ 4X Acc:636 BWR half-sib hybrid population showed significantly $(p<0.05)$ greater DMY than its 4 X Acc:636 BWR parent population, averaged over both years and both locations (Table 2). Conversely, DMY of the 4X 'Trailhead' CWR $\times 4$ X Acc:636 BWR half-sib hybrid population was significantly $(p<0.05)$ lower than its $4 \mathrm{X}$ 'Trailhead' BWR parent population (Table 2). Dry matter yield of the 4 X Acc:641.T CWR $\times 4$ X Acc:636 BWR half-sib hybrid population was not significantly different $(p<0.05)$ from the three release varieties of BWR at Providence but it was significantly lower $(p<0.05)$ than 'Continental' and 'Trailhead' at the Tintic location. Moreover, DMY of the synthetic-hybrid $8 X$ ' Continental' BWR population was equal to or significantly $(p<0.05)$ greater than either of its parental populations, 'Trailhead' or 'Magnar', at the Tintic location and ranked highest based on the overall averages (Table 2).

Table 2. Dry matter yield $\left(\mathrm{Mg} \cdot \mathrm{ha}^{-1}\right)$ for tetraploid (4X) and octoploid (8X) populations of basin wildrye $($ BWR), creeping wildrye $(\mathrm{CWR}) \times$ BWR half-sib hybrids $(\mathrm{HSH})$, and CWR $\times$ BWR full-sib hybrids (FSH) in spaced-plant dryland range plots evaluated over two years and two locations (Providence and Tintic) in Utah. Significant differences among groups of entry means are indicated by lettered ranks, within table columns, based on least significant difference.

\begin{tabular}{cccc}
\hline Population & Providence & Tintic & Avg. \\
\hline 4X Acc:636 BWR & $0.9 \mathrm{c}$ & $0.8 \mathrm{de}$ & $0.9 \mathrm{~d}$ \\
4X 'Trailhead' BWR & $1.6 \mathrm{~b}$ & $1.3 \mathrm{ab}$ & $1.5 \mathrm{~b}$ \\
8X 'Continental' BWR & $1.5 \mathrm{~b}$ & $1.6 \mathrm{a}$ & $1.5 \mathrm{~b}$ \\
8X 'Magnar' BWR & $1.4 \mathrm{~b}$ & $1.2 \mathrm{bc}$ & $1.3 \mathrm{bc}$ \\
4X Acc:641.T CWR $\times$ 4X Acc:636 HSH & $1.4 \mathrm{~b}$ & $1.0 \mathrm{~cd}$ & $1.2 \mathrm{c}$ \\
4X Acc:641.T CWR $\times$ 4X 'Trailhead' HSH & $0.9 \mathrm{c}$ & $0.7 \mathrm{e}$ & $0.8 \mathrm{~d}$ \\
4X 'Rio' CWR $\times$ 'Trailhead' BWR FSH & $2.8 \mathrm{a}$ & - & $2.8 \mathrm{a}$ \\
Standard error & 0.1 & 0.1 & 0.1 \\
Average & 1.5 & 1.3 & 1.4 \\
\hline
\end{tabular}

For comparison, the relative dry matter yields among two 4X Acc:641 CWR $\times$ 4X Acc:636 BWR single-cross hybrid genets (TC1 and TC2) and their parent populations (4X Acc:641 CWR and 4X Acc:636 BWR) from other experiments conducted over four years at Hyde Park and Tetonia (Table S1), were summarized here (Table 3). Moreover, field evaluations at the Hyde Park and Tetonia sites also 
included other important reference populations such as 'Rio' CWR, 'Trailhead' BWR, 'Continental' BWR, 'Magnar' BWR, 'Alkar' tall wheatgrass, 'Mustang' Altai wildrye (Leymus angustus), and four switchgrass cultivars ('Alamo', 'Dacotah', 'Falcon' and 'Sunburst'). 'Falcon' was the only switchgrass cultivar that successfully established and persisted at both locations, Hyde Park and Tetonia, thus it was the only one reported (Table 3). Dry matter yield variation among CWR $\times$ BWR s hybrid genets and other reference populations, at Hyde Park and Tetonia, was significantly influenced $(p<0.001)$ by population and there was a significant interaction of population $\times$ location $(p<0.01)$. Yields of the $4 \mathrm{X}$ Acc:641 CWR $\times$ 4X Acc:636 TC1 and TC2 single-cross hybrid genets were significantly higher than their 4X Acc:641 CWR parent population and yields of the TC1 hybrid were significantly greater than the 4X Acc:636 BWR high-parent. However, yields of the TC1 single-cross hybrid genet were not significantly different than the other BWR cultivars (Table 3). Moreover, it was also important to note that the 4X Acc:641.T CWR genet and 4X Acc:641 CWR reference population displayed substantially lower yields compared to all other populations including the $4 \mathrm{X}$ 'Rio' CWR cultivar (Table 3). These CWR reference populations were not included in other field experiments reported herein, in part because their aggressive rhizomes are difficult to manage and also because initial hybrid field evaluations, conducted at Hyde Park and Tetonia, showed that BWR is the higher-yielding reference parent (Table 3).

Table 3. Dry matter yield $\left(\mathrm{Mg} \cdot \mathrm{ha}^{-1}\right)$ for tetraploid (4X) and octoploid (8X) forms of basin wildrye $(B W R)$, creeping wildrye (CWR), CWR $\times$ BWR single-cross hybrids $(\mathrm{SCH})$, Altai wildrye (AWR), switchgrass (SG), and tall wheagrass (TWG) in dryland range plots evaluated over four years and two locations (Hyde Park, Utah and Tetonia, Idaho). Differences among groups of entry means are indicated by lettered ranks, within table columns, based on least significant difference.

\begin{tabular}{cccc}
\hline Population & Hyde Park & Tetonia & Avg. \\
\hline 4X Acc:636 BWR & $5.1 \mathrm{~d}$ & $4.8 \mathrm{ab}$ & $5.7 \mathrm{~cd}$ \\
4X 'Trailhead' BWR & $7.8 \mathrm{ab}$ & $4.6 \mathrm{ab}$ & $7.1 \mathrm{ab}$ \\
8X ‘Continental' BWR & $7.1 \mathrm{ab}$ & $5.9 \mathrm{a}$ & $7.5 \mathrm{ab}$ \\
8X 'Magnar' BWR & $6.7 \mathrm{bc}$ & $6.1 \mathrm{a}$ & $7.1 \mathrm{ab}$ \\
4X Acc:641 CWR & $2.5 \mathrm{e}$ & $1.5 \mathrm{de}$ & $2.3 \mathrm{f}$ \\
4X Acc:641 CWR.T genet & $1.9 \mathrm{e}$ & $1.0 \mathrm{e}$ & $1.7 \mathrm{f}$ \\
4X 'Rio' CWR & $4.5 \mathrm{~d}$ & $4.2 \mathrm{abc}$ & $4.8 \mathrm{de}$ \\
4X Acc:641 CWR × 4X Acc:636 BWR TC1 SCH & $7.2 \mathrm{ab}$ & $6.0 \mathrm{a}$ & $7.8 \mathrm{a}$ \\
4X Acc:641 CWR × 4X Acc:636 BWR TC2 SCH & $5.6 \mathrm{~cd}$ & $4.1 \mathrm{bc}$ & $5.4 \mathrm{~cd}$ \\
'Alkar' TWG & $8.2 \mathrm{a}$ & $4.5 \mathrm{abc}$ & $6.4 \mathrm{bc}$ \\
'Falcon' SG & $4.6 \mathrm{~d}$ & $2.1 \mathrm{de}$ & $3.8 \mathrm{e}$ \\
'Mustang' AWR & $4.8 \mathrm{~d}$ & $2.9 \mathrm{~cd}$ & $4.0 \mathrm{e}$ \\
Standard error & 0.5 & 0.6 & 0.4 \\
Average & 5.5 & 4.0 & 5.3 \\
\hline
\end{tabular}

\subsection{Biomass Yields in an Irrigated Production System}

Dry matter yield of two CWR $\times$ BWR half-sib hybrid populations was evaluated relative to other perennial grasses, including three released varieties of BWR, and two species mixtures, in a two-harvest irrigated production system at the Western Colorado Agriculture Experiment Station, Fruita location (Table S1).

Dry matter yield showed significant effects $(p<0.001)$ for population, year, harvest, and relative regrowth (difference between late- and early-season harvests). All two-way interactions and the three-way interactions among these four fixed effects were also significant $(p<0.001)$. Combined overall years and harvests, 'Alkar' tall wheatgrass produced significantly $(p<0.05)$ more dry matter than any other population (Table 4), but it also had significantly lower relative regrowth values indicating that it showed the greatest DMY decline from early-season to late-season harvests. Moreover, DMY of 'Alkar' tall wheatgrass was not significantly greater than the switchgrass variety mixture in the third and fourth evaluation years. Switchgrass consistently produced significantly $(p<0.05)$ more dry matter in the late-season harvest, overall years, compared to any of the other perennial grasses evaluated in this 
study (Table 4). Switchgrass also had significantly greater relative regrowth (Table 4), meaning that it produced relatively low DMY in the early-season harvest and relatively high DMY in the late-season harvest compared to the cool-season grasses. The overall DMY of the 'Trailhead' BWR variety was significantly greater $(p<0.05)$ than the 'Continental' and 'Magnar' BWR populations, and it was also significantly greater $(p<0.05)$ than the 4 X Acc:641.T CWR $\times 4$ X Acc:636 BWR half-sib hybrid population. However, the overall DMY of the 'Trailhead' BWR variety was not significantly greater than the 4X Acc:641.T CWR $\times 4 X$ 'Trailhead' BWR half-sib hybrid population. The 4X Acc:641.T CWR $\times 4 X$ 'Trailhead' BWR half-sib hybrid population showed significantly greater $(p<0.05)$ relative regrowth than its 'Trailhead' BWR parent population, which in this case indicated that the hybrid showed less DMY decline between the early- and late-season harvests (Table 4).

Table 4. Dry matter yield $\left(\mathrm{Mg} \cdot \mathrm{ha}^{-1}\right)$ for basin wildrye (BWR), creeping wildrye $(\mathrm{CWR}) \times \mathrm{BWR}$ half-sib hybrids (HSH), Altai wildrye (AWR), intermediate wheatgrass (IWG), switchgrass (SG), and tall wheatgrass (TWG) in a two-harvest, irrigated production experiment at the Western Colorado Agriculture Experiment Station. Significant differences among groups of entry means are indicated by lettered ranks, within table columns, based on least significant differences.

\begin{tabular}{|c|c|c|c|c|c|c|c|c|}
\hline Population & Year 1 & Year 2 & Year 3 & Year 4 & Early Cut & Late Cut & $\% \Delta^{1}$ & Avg. Total \\
\hline 4X ‘Trailhead’ BWR & $9.9 c-e$ & $20.2 \mathrm{~b}$ & $9.4 \mathrm{~b}$ & $17.9 \mathrm{bc}$ & $9.4 \mathrm{~b}$ & $4.9 \mathrm{de}$ & $-47 d$ & $14.3 \mathrm{~b}$ \\
\hline 8X 'Continental' BWR & 9.0 ef & $18.3 \mathrm{bc}$ & $7.5 \mathrm{~cd}$ & $16.5 \mathrm{c}$ & $7.8 \mathrm{~cd}$ & 5 de & $-36 c$ & $12.8 \mathrm{c}-\mathrm{e}$ \\
\hline 8X 'Magnar' BWR & $9.2 \mathrm{~d}-\mathrm{f}$ & $18.4 \mathrm{bc}$ & $7.5 \mathrm{~cd}$ & $13.7 \mathrm{~d}$ & $7.6 \mathrm{~cd}$ & $4.7 \mathrm{e}$ & $-38 c$ & $12.2 \mathrm{e}$ \\
\hline 4X Acc:641.T CWR $\times 4 \mathrm{X}$ 'Trailhead' BWR HSH & $10.3 \mathrm{~cd}$ & $17.6 \mathrm{~cd}$ & $7.9 \mathrm{~cd}$ & $17.5 \mathrm{c}$ & $8.0 \mathrm{c}$ & $5.4 \mathrm{~cd}$ & $-33 c$ & $13.3 \mathrm{~b}-\mathrm{e}$ \\
\hline 'Mustang' AWR & $10.4 \mathrm{c}$ & $18.0 \mathrm{~b}-\mathrm{d}$ & $9.7 \mathrm{~b}$ & $16.8 \mathrm{c}$ & $7.2 \mathrm{~d}$ & $6.5 \mathrm{~b}$ & $-5 b$ & $13.7 \mathrm{~b}-\mathrm{d}$ \\
\hline 'Rush' IWG & $12.7 \mathrm{~b}$ & $18.3 \mathrm{bc}$ & $8.5 \mathrm{bc}$ & $16.5 c$ & $9.1 \mathrm{~b}$ & $4.9 \mathrm{de}$ & $-46 \mathrm{~d}$ & $14.0 \mathrm{bc}$ \\
\hline 'Alkar' TWG & $14.8 \mathrm{a}$ & $23.0 \mathrm{a}$ & $11.1 \mathrm{a}$ & $20.1 \mathrm{ab}$ & $11.6 \mathrm{a}$ & $5.7 \mathrm{c}$ & $-51 \mathrm{e}$ & $17.3 \mathrm{a}$ \\
\hline Standar error & 0.4 & 0.8 & 0.5 & 1.0 & 0.3 & 0.3 & 0.3 & 0.4 \\
\hline average & 10.8 & 18.4 & 8.8 & 17.4 & 8.4 & 5.5 & -35 & 13.9 \\
\hline
\end{tabular}

${ }^{1}$ Percent change $(\% \Delta)$ calculated as (early cut yield—late cut yield) $\cdot 100 /($ early cut yield).

\subsection{Summarized Analysis of Biomass Yield from Dryland and Irrigated Testing Sites}

A summarized analysis of overall years and testing sites was performed by nesting populations within groups including the 8X BWR, 4X BWR, 4X CWR, 4X CWR $\times 4$ X BWR hybrids (Table 5). Significant variation $(p<0.0001)$ was detected for fixed effects of locations, years, population within group, and group. However, these results (Table 5) should be viewed cautiously because not all populations were tested at all sites. In fact, the only populations that were tested across all sites were 'Trailhead' BWR, 'Continental' BWR, 'Magnar' BWR, and the 4X Acc:641 CWR $\times$ 4X Acc:636 BWR hybrids (as single-cross or half-sib hybrids). This meta-analysis shows that BWR and 4 X CWR $\times 4 X$ BWR hybrids displayed significantly more dry matter yield than CWR at dryland sites and suggests that this could be extrapolated to other sites, even though CWR was only tested at two of the four dryland testing sites (Table 5). This meta-analysis also shows that 8X BWR performed better than 4X BWR in dryland environments, whereas 4X BWR performed better than 8X BWR in the irrigated environment (Table 5). Estimated yields of the 4 X CWR $\times 4 X$ BWR hybrids including all half-sib hybrids, full-sib hybrids, and single-cross hybrids were significantly less than 8X BWR in dryland environments, significantly less than $4 \mathrm{X}$ BWR in the irrigated environment, but not significantly different from $4 \mathrm{X}$ or $8 \mathrm{X}$ BWR overall (Table 5). The estimated yield of switchgrass in dryland environments was based only on the best of four populations, where three populations failed to flourish, at only two of the four sites. Thus, estimated yield of switchgrass in dryland environments should also be viewed cautiously. 
Table 5. Dry matter yield estimates for tetraploid (4X) and octoploid (8X) forms of basin wildrye (BWR), creeping wildrye (CWR), CWR $\times$ BWR hybrids, Altai wildyre (AWR), intermediate wheatgrass (IWG), switchgrass (SG), and tall wheatgrass (TWG) across four dryland ranges and one irrigated testing environment. Significant differences among groups of entry means are indicated by lettered ranks based on least significant difference.

\begin{tabular}{cccc}
\hline Population & Dryland Range & Irrigated & Overall \\
\hline 4 X BWR & $4.0 \mathrm{~b}$ & $14.3 \mathrm{~b}$ & $5.6 \mathrm{~b}$ \\
8 X BWR & $4.4 \mathrm{a}$ & $12.5 \mathrm{~d}$ & $5.5 \mathrm{~b}$ \\
4 X CWR & $0.6 \mathrm{~d}$ & - & $2.7 \mathrm{c}$ \\
4 X CWR $\times 4$ X BWR & $4.2 \mathrm{ab}$ & $13.0 \mathrm{~cd}$ & $5.8 \mathrm{~b}$ \\
AWR & $2.0 \mathrm{c}$ & $13.7 \mathrm{bc}$ & $5.2 \mathrm{~b}$ \\
IWG & - & $14.0 \mathrm{~b}$ & $6.1 \mathrm{~b}$ \\
SG & $1.6 \mathrm{c}$ & $14.3 \mathrm{~b}$ & $5.0 \mathrm{~b}$ \\
TWG & $4.7 \mathrm{ab}$ & $17.3 \mathrm{a}$ & $8.3 \mathrm{a}$ \\
Standard error & 0.2 & 0.5 & 0.3 \\
Average & 3.1 & 14.1 & 5.5 \\
\hline
\end{tabular}

\section{Discussion}

\subsection{Development and Testing of $C W R \times B W R$ Hybrids}

Our study demonstrated useful methods of producing hybrid seed for allogamous plants on a field scale, which has been a considerable challenge in perennial grass breeding $[15,26]$. Our approach worked effectively for crosses of 4 X CWR and 4 X BWR, but it did not work in crosses of 4 X CWR and $8 X$ BWR. One possible reason for low production of $4 X C W R \times 8 X$ BWR hybrids may be delayed flowering of the $8 \mathrm{X}$ BWR populations. However, other intrinsic fertility barriers such as abnormal endosperm development are expected from interploidy crosses of $4 \mathrm{X}$ CWR and 8X BWR, 4X and 8X BWR, or 4X and $8 \mathrm{X}$ switchgrass interploidy hybrids $[40,41]$. This is why chromosome doubling of $4 \mathrm{X}$ 'Trailhead' BWR was required to make the $8 X$ 'Continental' interploidy hybrid of $4 X$ 'Trailhead' and $8 X$ 'Magnar' BWR cultivars. Thus, reproductive incompatibility mechanisms such as the endosperm genic balance number requirement [41] explain the prevalence of relatively light seed and poor germination of seed obtained from the 4X CWR $\times 8 X$ BWR hybridization plots (Table 1). Most of the seed from the 4X CWR $\times 8 \mathrm{X}$ BWR hybridization plots that did germinate was derived from self-pollination or pollination by 4 X BWR from other hybridization plots. Conversely, all of the seed sampled from $4 \mathrm{X}$ CWR $\times 4 \mathrm{X}$ BWR hybridization plots was of hybrid origin with relatively high seed weights and germination rates. The average estimated seed yields of the 4X Acc:641.T CWR genet within hybridization plots containing 4X BWR (Table 1) were about five-fold lower than the reported seed yield averages of about $336 \mathrm{~kg} \cdot \mathrm{ha}^{-1}\left(33.6 \mathrm{~g} \cdot \mathrm{m}^{-2}\right)$ from 'Rio' CWR [42]. However, it is impossible to say whether our yields were limited by inherent limitations of this technique, such as gamete incompatibility, or other factors such as differences in the productivity of CWR genotypes or environments.

The half-sib $4 \mathrm{X}$ CWR $\times 4 \mathrm{X}$ BWR hybrid populations are similar to that of semi-hybrids of grass or alfalfa [43-46] in the sense that the hybrids are comprised of genetically heterogeneous individuals, but different in that virtually all of the seeds harvested from the 4 X CWR seed parent were hybrids. The semi-hybrids, in contrast, contain an equal mixture hybrid and parental populations [43-46]. With prolific production of rhizomes and tillers, clonal production of the CWR seed parent is feasible. This approach of half-sib hybrid seed production, using one clonally propagated seed parent, creates opportunity to select individual genets that have good combining ability and also provides a rapid way to introduce novel genes into hybrid populations. Although similar approaches of producing full-sib single-cross hybrids has been proposed by clonal propagation of two self-incompatible genets, the difficulty of clonal propagation limits the application of this approach in perennial ryegrass (Lolium perenne) or switchgrass [15]. 
As a group, $4 \mathrm{X} C W R \times 4 \mathrm{X}$ BWR hybrids showed yields that were at least equal to their $4 \mathrm{X}$ BWR parental populations, overall sites, and significantly higher than CWR yields in dryland environments (Table 5). Moreover, 4X BWR populations displayed substantially and statistically greater yields than 4X CWR in dryland environments (Tables 3 and 5). Thus, we cautiously assume that our 4X CWR $\times 4 \mathrm{X}$ BWR hybrid populations show indication of mid-parent heterosis if their yields are equivalent to their $4 X$ BWR parent populations and show indication of high-parent heterosis if their yields are significantly greater than their $4 \mathrm{X}$ BWR parent populations in dryland range growing environments. The 4X Acc:641.T CWR $\times$ 4X Acc:636 BWR half-sib hybrid population showed a significant 33\% advantage over its $4 \mathrm{X}$ Acc:636 BWR parent population at the Providence and Tintic testing sites (Table 2), indicating possible high-parent heterosis of this half-sib hybrid. One of the 4X Acc:641 CWR $\times 4$ X Acc:636 BWR single-cross hybrid genets also displayed a significant $36 \%$ yield advantage over the 4X Acc:636 BWR population at the Hyde Park and Tetonia testing sites (Table 3), which may indicate high-parent heterosis, but we did not have the actual 4X Acc:636 parent plant that was needed as a reference for this single-cross hybrid. Nevertheless, the 4X Acc:636 BWR parent population and both 4X Acc:641 CWR $\times$ 4X Acc:636 BWR single-cross hybrids all showed at least two-to three-fold greater yields than the 4X Acc:641.T CWR genet or 4X Acc:641 CWR population at the Hyde Park and Tetonia testing sites (Table 3). Thus, we conclude that yields of 4X Acc:641.T CWR $\times$ 4X Acc:636 BWR hybrids show indications of high-parent heterosis at the Providence and Tintic testing sites (Table 2) and that the 4X Acc:641 CWR $\times$ 4X Acc:636 BWR single-cross hybrids showed indications of mid-parent and possible high-parent heterosis at the Hyde Park and Tetonia testing sites (Table 3). Yields of the 4X 'Rio' CWR $\times 4$ X 'Trailhead' BWR full-sib hybrid population were $75 \%$ greater than its 4 X 'Trailhead' BWR parent population at the Providence site (Table 2) and the $4 \mathrm{X}$ 'Trailhead' BWR population showed yields that were nearly 50\% greater than the $4 \mathrm{X}$ 'Rio' CWR at the Hyde Park and Tetonia sites (Table 3). Therefore, the 4 X 'Rio' CWR $\times 4$ X 'Trailhead' BWR full-sib hybrid population also showed indications of high-parent heterosis by outperforming its $4 X$ 'Trailhead' BWR parent population by a $75 \%$ margin. Although yields of $4 \mathrm{X} C W R \times 4 X$ BWR hybrid populations were slightly but not significantly greater than 4X BWR populations' overall dryland environments (Table 5), the 4X Acc:641 CWR.T $\times 4 \mathrm{X}$ 'Trailhead' BWR half-sib hybrid performed much worse than its $4 X$ 'Trailhead' BWR population at the Providence and Tintic dryland testing sites (Table 2), indicating that performance of this hybrid may be more similar to its presumed low-parent, 4 X Acc:641 CWR.T.. As a group, yields of the 4 X CWR $\times 4 \mathrm{X}$ BWR hybrids were significantly less than estimated yields of the 4X BWR populations in the irrigated testing site (Table 5), but yields of the 4X Acc:641.T CWR $\times 4$ X 'Trailhead' BWR half-sib hybrid were significantly less than its $4 \mathrm{X}$ 'Trailhead' BWR parent population in this two-harvest irrigated management system (Table 4). Thus, we conclude that some but not all 4X CWR $\times 4 X$ BWR hybrids show indications of high-parent heterosis in dryland environments. Although performance of $4 \mathrm{X}$ CWR $\times 4$ X BWR half-sib hybrids was comparable to 4 X BWR in the two-harvest irrigated production system, there were no indications of high-parent heterosis in this type of management system. Thus, it seems that heterosis in the $4 \mathrm{XCWR} \times 4 \mathrm{X}$ BWR hybrids showed stronger indications of expression in the less competitive conditions of space-planted plots, which was also true for population hybrids of perennial ryegrass [46].

Dryland biomass yields of the 4 X 'Rio' CWR $\times 4$ X 'Trailhead' BWR single-cross hybrid population were at least two-fold greater than biomass yields of either of the two half-sib hybrid populations produced by the 4 X Acc:641.T CWR genet. One factor that may explain higher yields of the 4 X 'Rio' CWR $\times 4$ X 'Trailhead' BWR hybrid is that the 4 X 'Rio' CWR showed about two- to three-fold greater yields than 4 X Acc:641 CWR population or 4X Acc:641.T CWR genet, respectively, in dryland yield trials conducted at Hyde Park and Tetonia. Also, the 4 X 'Trailhead' BWR showed significantly greater yields than the other 4X BWR parent, Acc:636, used in this study (Tables 2 and 3). Delayed flowering may be another factor that may have contributed to relatively strong heterosis expressed in the $4 \mathrm{X}$ 'Rio' CWR $\times 4 \mathrm{X}$ 'Trailhead' BWR hybrid. It has been shown that delayed flowering can be a strong driver of biomass yield in switchgrass hybrids [27]. In our observations, 'Rio' CWR and the 4X 'Rio' 
$C W R \times 4 X$ 'Trailhead' BWR hybrid flowered about one week later than the 4X BWR, 4X Acc:641 CWR, or 4X Acc:641 CWR $\times 4$ X BWR populations. Biomass yields up to $11.5 \mathrm{Mg} \cdot \mathrm{ha}^{-1}$ per year with saline irrigation water and repeated harvesting have been reported for 'Rio' CWR in the San Joaquin Valley of California [37]. Thus, an important future goal will be to generate half-sib hybrid seed for the cross of $4 \mathrm{X}$ 'Rio' CWR $\times 4 \mathrm{X}$ 'Trailhead' BWR and test these hybrids in multiple dryland and irrigated environments of California, Colorado, Nevada, and Utah where BWR and CWR may be useful as biomass feedstocks $[12,37]$. In any case, comparisons of hybrids made using two different CWR genets-4X Acc:641.T and one 4X 'Rio' plant-indicate that the identification and selection of superior CWR seed-parents, as well as superior BWR pollen parents, may be the fastest and most promising approach to develop higher-yielding CWR $\times$ BWR hybrids and native grass bioenergy feedstocks for western North America.

\subsection{Dryland Yield Potential of Perennial Grasses in Cold-Desert Environments}

Average yearly dryland biomass yields ranging from 2.2 to $9.6 \mathrm{Mg} \cdot \mathrm{ha}^{-1}$ for the $4 \mathrm{X}$ Acc:636 BWR population were previously reported based on testing over four years and two locations near Hyde Park, Utah and Tetonia, Idaho [14] but otherwise we are not aware of any other published reports on non-irrigated biomass yields of BWR in its native range environments. The average yearly dryland biomass yields of the $4 \mathrm{x}$ Acc:636, $4 \mathrm{X}$ 'Trailhead', 8X 'Continental', and 8X 'Magnar' BWR populations ranged from 0.5 to $2.1 \mathrm{Mg} \cdot \mathrm{ha}^{-1}$ at Providence and Tintic (Table 2), whereas the average yearly biomass yields of these same four populations ranged from 2.2 to $13.3 \mathrm{Mg} \cdot \mathrm{ha}^{-1}$ at the Hyde Park and Tetonia testing sites (Table 3). Thus, dryland biomass yields from experiments conducted at the Providence and Tintic sites were lower than previously described experiments conducted at the Hyde Park and Tetonia testing sites [14]. One possible explanation for these differences is that plant densities in the Hyde Park and Tetonia sites were twice as high as the Providence and Tintic sites. The plants at Providence and Tintic were, however, simply less vigorous. Under these conditions, we would expect BWR plants to grow larger, not smaller, at the lower plant densities such as those used at Providence and Tintic $\left(1\right.$ plant $\left.\cdot \mathrm{m}^{-2}\right)$. Although the Tetonia and Tintic testing sites are located in dissimilar environments (Table S1), the Hyde Park and Providence sites were located at nearly identical elevations in the same valley, only $12.8 \mathrm{~km}$ apart, with the same soil types (Nibley silty clay loam). The average yearly biomass yields at Hyde Park and Tetonia varied nearly three-fold, between 3.1 and $8.6 \mathrm{Mg} \cdot \mathrm{ha}^{-1}$, over four harvest years (Table 3), indicating that seasonal variations in climate can have dramatic effects on perennial grass productivity especially under low-input management. However, other factors probably contributed to differences between evaluations conducted at the Providence and Tintic sites (Table 2) versus the Hyde Park and Tetonia sites (Table 3). Nevertheless, the $4 X$ 'Trailhead' BWR population ranked relatively high and the $4 \mathrm{X}$ Acc: $636 \mathrm{BWR}$ population ranked relatively low across all dryland environments (Tables 2 and 3). Moreover, 8 X BWR populations performed significantly better across all dryland range testing sites (Table 5). These results demonstrate significant genetic variation for BWR biomass yields within its native growing environments. Wide variation in the average yields among sites, and significant genotype by environment interactions, observed across our dryland testing sites also demonstrate the importance of testing plant materials over multiple locations and years.

The average total biomass yields of all four BWR populations, two CWR $\times$ BWR single-cross hybrid genets, and tall wheatgrass were all significantly greater than the best of four switchgrass varieties tested in non-irrigated experiments conducted at Hyde Park and Tetonia (Table 3). This was not surprising considering that these relatively high elevation, cold-desert testing sites are not located within the native range of switchgrass [1,5]. However, there did appear to be some variation for adaptation to these environments, among the four switchgrass varieties tested, and it was interesting that the best adapted variety, Falcon, was an upland ecotype originating from relatively high-elevations $(1517 \mathrm{~m})$ in New Mexico on the western range of switchgrass distribution [5]. Falcon did not perform as well as Dacotah in high-latitude regions of Europe [47], but it did perform better than Dacotah in our high-elevation cold-desert testing sites (Table S1). Additional screening and breeding research 
may help identify and develop switchgrass populations that perform better in cold high-latitude or high-elevation growing environments [48], such as those found in western North America.

Although 'Alkar' tall wheatgrass was clearly the best yielding population in the irrigated testing environment, it is interesting that overall dryland biomass yields of BWR cultivars and the 4X Acc:641 CWR $\times 4$ X Acc:636 BWR TC2 single-cross hybrid genet were equal to or significantly greater than 'Alkar' tall wheatgrass (Table 3). Tall wheatgrass was introduced and widely naturalized throughout North America [13], and has proven to be a high yielding cool-season grass in other non-irrigated field evaluations in studies conducted in western North Dakota [6] and Kansas [9].

\subsection{Irrigated Yield Potential of Perennial Grasses in Cold-Desert Environments}

The early-season biomass yields and average yearly biomass yields of perennial grasses including 'Trailhead' BWR, 'Alkar' tall wheatgrass, and switchgrass evaluated in our two-harvest irrigated production experiment in western Colorado can be compared to the total annual yields in a single-harvest irrigation system in western Nevada [12]. In the single-harvest evaluation conducted in western Nevada, DMY values of 'Trailhead' BWR and 'Alkar' tall wheatgrass averaged 7.2 and $7.3 \mathrm{Mg} \cdot \mathrm{ha}^{-1}$ under low-water treatments (71 cm water annually) or 8.7 and $9.9 \mathrm{Mg} \cdot \mathrm{ha}^{-1}$ in the high irrigation (120 cm water annually) treatment, respectively [12]. These values from single-harvest irrigated field trial [12] were similar but slightly lower than the average early-season harvest yields of 'Trailhead' BWR and 'Alkar' tall wheatgrass from western Colorado (Table 4). Since all of the cool-season grasses evaluated in the two-harvest irrigated production experiment were in the anthesis or post-anthesis stage of development on the early-harvest dates, we believe that they would have reached maximum or near-maximum annual yields in a single-harvest system. However, this was not true for switchgrass, which was not yet flowering and did not have a chance to reach maximum biomass accumulation values on the early-harvest dates in this two-harvest experiment (Table 4). Nevertheless, the switchgrass yields from both the early- and late-harvests in western Colorado (Table 4) were similar to the observed DMY of $7.8 \mathrm{Mg} \cdot \mathrm{ha}^{-1}$ in the high-water treatment in western Nevada and substantially greater than $2.8 \mathrm{Mg} \cdot \mathrm{ha}^{-1}$ observed in the low-water treatment [12]. Although the timing of our early-season harvest was optimized for cool-season grasses, it provided time for all of the perennial grasses, including switchgrass, to regrow and produce significantly more yearly total biomass (Table 4) than the single-harvest irrigated production system used in western Nevada [12]. The overall biomass yields showed nearly three-fold variation, from 5 to $15 \mathrm{Mg} \cdot \mathrm{ha}^{-1}$, over three years in Nevada [12] and over two-fold variation over four years in Colorado (Table 4).

The average yearly total yields of 'Alkar' tall wheatgrass, Rush intermediate wheatgrass, and switchgrass from our two-harvest irrigated evaluation in western Colorado (Table 4) can be compared to the average yearly total yields from another multiple-harvest irrigated study, conducted in northern Utah, containing these same species [11]. The average yearly total yields of 'Alkar' tall wheatgrass and Rush intermediate wheatgrass from Colorado (Table 4) were substantially lower than the maximum DMY values of 27.6 and $26.8 \mathrm{Mg} \cdot \mathrm{ha}^{-1}$ observed for these same varieties, respectively, at the optimum water level of a five-harvest irrigated production evaluation in northern Utah [11]. Yet, the average yearly total DMY of one switchgrass variety mixture tested in the two-harvest irrigated production system (Table 4) was very similar to the average yearly total of about $14.0 \mathrm{Mg} \cdot \mathrm{ha}^{-1}$ observed for the four switchgrass varieties tested in the five-harvest irrigated production system [11]. Thus, with adequate irrigation, switchgrass was competitive with cool-season grasses in one-harvest [12] and two-harvest management systems (Table 4), but substantially greater yields can be attained from repeated harvesting of cool-season grasses including tall wheatgrass and intermediate wheatgrass [11]. Comparisons of these three studies suggest that something, perhaps cool-nights, may be impeding regrowth of warm-season grasses with repeated harvests in these high-elevation cold-desert environments. The early-season DMY values of tall wheatgrass and intermediate wheatgrass were greater than switchgrass in multiple-harvest studies conducted in Utah [11] and Colorado (Table 4), whereas the late-season yields of switchgrass were always greater 
than cool-season grasses in both studies, over all irrigation levels [11]. Presumably this difference in yield phenology is related to the $\mathrm{C} 4$ photosynthesis system of switchgrass and the low-temperature growth potential of cool-season grasses.

Although early-season yields of 'Trailhead' BWR were substantially greater than switchgrass, the average total yields were not significantly different in the two-harvest irrigated experiment in Colorado (Table 4) or either of the two irrigation treatment levels tested in Nevada [12]. The early-season and average total biomass yields of 'Alkar' tall wheatgrass were both significantly greater than switchgrass in the two-harvest irrigated experiment in Colorado (Table 4) and the low-water treatment in the one-harvest experiment conducted in Nevada [12]. The average total biomass yields of 'Alkar' tall wheatgrass was nearly two-fold higher than the best of four switchgrass varieties at the highest water levels and more than three-fold higher at the lowest water levels in the five-harvest irrigated experiment in Utah [11]. Thus, results from irrigated production systems in Colorado (Table 4), Nevada [12] and Utah [11] indicate that cool-season grasses such as BWR, intermediate wheatgrass, and tall wheatgrass could be better than switchgrass when irrigation water supplies are limited in the cold-desert environments of western North America.

Significant variance among the relative regrowth of cool-season grasses (Table 4) may reflect dissimilarities in phenology or defoliation tolerance. Tall wheatgrass displayed significantly greater yield declines from early- to late-season harvests, compared to other grasses (Table 4), which might be related to its relatively late flowering times. Yield declines of the $4 \mathrm{X}$ 'Trailhead' BWR population were significantly greater than the 4 X Acc:641.T CWR $\times 4$ X 'Trailhead' BWR hybrid. The most obvious explanation for this is that CWR and the interspecific hybrids are much more rhizomatous and produce more tillers than BWR, which may provide mechanisms for better defoliation tolerance and regrowth potential [14,39]. Expression of rhizomatousness in the CWR $\times$ BWR hybrids is largely controlled by a combination of two recessive genes: one dominant gene, and one partially-dominant gene with major effects $[14,39]$. We are not aware of any other differences in phenology or physiology that would likely explain differences in the regrowth potential between BWR and the CWR $\times$ BWR hybrids. However, it was somewhat surprising that most of the BWR and CWR $\times$ BWR plant materials displayed significantly less yield declines, from early- to late-season harvests, compared to tall wheatgrass or intermediate wheatgrass. Native range grasses, such as BWR, are usually not included in multiple-harvest production systems, such as the five-harvest irrigated production trial conducted in northern Utah [11], in part because they do not have the forage quality of conventional pasture grasses and also because it has been generally presumed that they do not have significant regrowth potential. In fact, to our knowledge, this is the first documented experiment involving seasonal regrowth of BWR in an irrigated production system. Thus, improved regrowth of the $4 \mathrm{X}$ Acc:641.T CWR $\times 4$ X 'Trailhead' BWR hybrid could be a potentially useful attribute of the CWR $\times$ BWR hybrids $[14,39]$.

Although yields of switchgrass from the two-harvest irrigated production study in Colorado (Table 4) were good, these yields have been surpassed in other environments. Average annual yields of upland and lowland switchgrass ecotypes ranged from 4 to $21 \mathrm{Mg} \cdot \mathrm{ha}^{-1}$ in single-harvest production experiments conducted across various latitudes of central North America, from 36 to $46^{\circ} \mathrm{N}$, including Kansas, Nebraska, Oklahoma, and Wisconsin where switchgrass is well adapted [28]. Switchgrass yields up to 26 and $33 \mathrm{Mg} \cdot$ ha $^{-1}$ have been reported in one- and two-harvest production systems in the southeastern parts of North America [1].

\section{Materials and Methods}

\subsection{Plant Materials Used for Making CWR $\times$ BWR Hybrids}

The term "population" was used herein as a generic term for individuals sampled from genetically heterogeneous cultivars, hybrids, or natural germplasm accessions. Plant materials used for making and testing experimental CWR $\times$ BWR hybrids included two tetraploid (4X) BWR populations, 
two octoploid (8X) BWR populations, and two 4X CWR populations. The BWR populations included 8X 'Continental', 4X 'Trailhead', and 8X 'Magnar' in addition to one natural 4X population Acc:636 collected near Lethbridge, Alberta sometime prior to 1974 by Sylvester Smoliak. 'Trailhead' originated from a natural population near Roundup, Montana and was released in 1991 [49]. 'Magnar' originated from a natural population in south-eastern British Columbia and was released sometime before 1995 [50]. The 4X CWR populations included a natural germplasm accession Acc:641 originally collected near Jamieson, Oregon in 1975 by Kay Asay and the cultivar 'Rio', which was originally collected from Kings Valley, California and released in 1991 [36].

The term "genet" was used herein to identify and reference clonally propagated individuals such as the two single-cross hybrids-TC1 and TC2-of 4X Acc:641 CWR $\times 4$ X Acc:636 BWR and the 4X Acc:641.T CWR plant used to make the full-sib pseudo-backcross families [51] and identify chromosome regions controlling biomass yield [14]. Both BWR and CWR are considered highly self-incompatible [52] and previous studies showed that the 4X Acc:641.T CWR genet was receptive to pollen from the TC1 and TC2 single-cross hybrids with less than $4 \%$ selfing using paper bags to cover its spike-inflorescences [51]. However, the quantities of seed produced by these techniques is insufficient for extensive testing in seeded field trials. Thus, we hypothesized that it would be possible to produce half-sib hybrid seed by growing the highly rhizomatous $4 \mathrm{X}$ Acc:641.T CWR genet in isolated "hybridization plots" with different $4 \mathrm{X}$ or 8X BWR populations, described above, as the only available pollen source. For purposes of testing other sources of CWR in hybrids with BWR, a new full-sib hybrid population was developed using paper bags to cover the spike-inflorescences of one $4 \mathrm{X}$ 'Rio' CWR plant and manually shaking pollen from extruded anthers of spikes from one $4 \mathrm{X}$ 'Trailhead' BWR genet.

\subsection{Description of Locations Used to Develop and Test CWR $\times$ BWR Hybrids}

All testing sites (Table S1) were located on properties of the Utah State University, Utah Agriculture Experiment Station; the Colorado State University, Western Colorado Research Center; or the University of Idaho, Eastern Idaho Agriculture Experiment Station. The average precipitation and temperature data was obtained from the Prism Climate Group [53] using geographic coordinates (Table S1) and 30-year normals (1981-2010) data setting at $800 \mathrm{~m}$ resolution. Precipitation data was summarized as seasonal averages for winter (December, January and February), spring (March, April and May), summer (June, July and August), and fall (September, October and November). The average, minimum, and maximum number of freeze-free days above $0{ }^{\circ} \mathrm{C}$ were determined using data available from the nearest station of similar elevation available from the Utah Climate Center [54].

\subsection{Evaluation of Half-Sib Hybrid Seed Production}

This study included an experiment designed to compare the yield and quality of seed from the 4X Acc:641.T CWR genet pollinated using the two 4X (Acc:636 and 'Trailhead') and the two 8X (Continental and 'Magnar') BWR populations as different fixed effects. The 4X Acc:641.T CWR genet was grown in isolated hybridization plots with each of the four different BWR pollen parent populations in a randomized complete block (RCB) design with four different hybridization plots (four different BWR pollen parents) within each block and three replicated blocks for a total of 12 hybridization plots. Beginning in December of 2007, rhizome propagules from the 4X Acc:641.T CWR genet and seedlings of the four BWR pollen parents were grown in a sufficient number of racked soil containers (4-cm diameter) to produce 972 clones of the 4X Acc:641.T CWR genet and 408 individual seedlings from each of the four BWR pollen parents. These plant materials were transplanted to a testing site near Richmond, Utah in the spring of 2008. Plants were irrigated after planting, but not irrigated during subsequent years of seed production. Each hybridization plot had three rows of the 4X Acc:641.T CWR genet flanked by two rows of the BWR pollen parent on each side. Rows were $13 \mathrm{~m}$ long with $0.91 \mathrm{~m}$ (36 inch) spacing between rows with plants spaced $0.5 \mathrm{~m}$ apart within rows. The hybridization plots were cultivated between rows and fertilized once per year with approximately 
$56 \mathrm{~kg} \mathrm{~N} \mathrm{ha}^{-1}$ in the fall (October) and $34 \mathrm{~kg} \mathrm{~N} \mathrm{ha}^{-1}$ in the spring (May) in the form of urea. Thus, the harvested CWR plot size was approximately $37 \mathrm{~m}^{2}$, not including space used by the BWR pollen parents. The 12 hybridization plots were tandemly arranged in seven parallel rows, with $13 \mathrm{~m}$ space between test plots, for a total length of $323 \mathrm{~m}$ and total width of $5.5 \mathrm{~m}$. The randomization scheme was restricted such that hybridization plots containing the $4 \mathrm{X}$ or $8 \mathrm{X}$ BWR pollen parents were alternated.

The total seed yield, average seed weight, and seed germination rates were measured using seed harvested from the 4 X Acc:641.T CWR genet in each of the 12 hybridization plots over the course of four years, from 2009 to 2012, using a plot combine (Wintersteiger Inc., Salt Lake City, Utah, USA). Additional fine threshing and cleaning was performed manually before the seed yield $\left(\mathrm{g} \cdot \mathrm{m}^{-2}\right)$ was determined for the harvested plot area $\left(37 \mathrm{~m}^{2}\right)$. Three sets of 100 seed were counted and weighed from each plot, each year, to determine the average seed weight $\left(\mathrm{mg} \cdot \mathrm{seed}^{-1}\right)$ and germination rates (\%). Germination rates were determined by treating each 100 -seed sample with tetramethythiuram disulfide, and then spreading each sample on blue germination blotter paper (Anchor Paper, St. Paul, Minnesota, USA) moistened with distilled water in $11 \times 11 \times 3.5-\mathrm{cm}$ Cont $156 \mathrm{C}$ germination boxes (Hoffman Manufacturing, Inc., Jefferson, Oregon, USA). Using standard seed testing procedures for CWR and BWR, seeds were imbibed for $3 \mathrm{~d}$ at $25^{\circ} \mathrm{C}$, stratified at $4{ }^{\circ} \mathrm{C}$ for $14 \mathrm{~d}$ in dark chambers, and then tested for germination in dark plant-growth chambers maintained on a diurnal cycle of $16 \mathrm{~h}$ at $15^{\circ} \mathrm{C}$ and $8 \mathrm{~h}$ at $25^{\circ} \mathrm{C}$. Germinated seeds were counted each week and until the final $28 \mathrm{~d}$ count.

\subsection{Genetic Testing of Half-Sib Hybrid Seed}

The genetic identity of seed produced by the 4X Acc:641.T CWR genet, from the first and second years of seed production, was tested by comparing it with representative genotypes of the CWR and BWR parents using a principle coordinate analysis of genetic distances based on comparisons of DNA profiles. Fresh leaf samples were lypholized and milled using a MM300 (Retsch Inc., Newtown, Pennsylvania, USA) mixer mill for DNA extraction using the DNeasy 96 Plant Kit (Qiagen, Germantown, Maryland, USA). Multi-locus DNA profiles of each DNA sample were developed using the AFLP technique [55] with modifications for detection using fluorescent labels and capillary electrophoresis. Briefly, the selective EcoRI primers were fluorescent labeled with 6-carboxyfluorescein and fractionated by capillary electrophoresis on an ABI3100 instrument (PE Applied Biosystems, Foster City, California, USA) with internal GS-500 size standards (PE Applied Biosystems) for each sample in each channel. The EcoRI and MseI preamplification primers both included one selective nucleotide $\mathrm{A}$ and $\mathrm{C}$, respectively. The selective amplification primers included two additional selective nucleotides in four different combinations including E36(ACC)/ /M61(CTG), E37(ACG)//M60(CTC), E38(ACT)//M60(CTC) and E41(AGG)//M47(CAA). Different AFLP markers were identified and scored for the presence or absence of bands (DNA amplicons) based on the relative mobility corresponding to about $1 \mathrm{bp}$ using Genographer open source software. A principle coordinates analysis of DNA profiles was performed using NTSYSpc, Numerical Taxonomy System version 2.21 (Exeter Software, Setauket, New York, USA) based on pairwise comparisons of genetic similarity among individual plants computed using the similarity index (S) formula $S_{X Y}=2 N_{X Y} /\left(N_{X}+N_{Y}\right)$, where $N_{X Y}$ is the number of shared bands and where $N_{X}$ and $N_{Y}$ are the numbers of bands in plants $X$ and Y. Population structure and ancestry coefficients of seed harvested from the 4X Acc:641.T CWR genet, in different hybridization plots, were also compared to BWR and CWR reference samples using Bayesian clustering [56,57] modeled a priori for possible admixture among the four expected base populations of 4X Acc:641 CWR, 4X Acc:636 BWR, 4X 'Trailhead' BWR, and 8X 'Magnar' BWR. All other genotypes were anticipated to be hybrid- or direct-descendants of these four base populations. Finally, statistical comparisons of genetic diversity within populations were based on the similarity index (S), based on unbiased estimates of the variance for $\mathrm{S}$ corrected for covariance [58]. 


\subsection{Evaluation of DMY in Dryland Range Environments}

In many cases, natural stands of BWR and other caespitose grasses grow with open spaces between plants rather than solid swards in the Great Basin region of western North America. Dry matter yields of experimental half-sib hybrid and full-sib hybrid populations were compared to the four BWR reference populations (Acc:636, 'Continental', 'Magnar', and 'Trailhead') in simulated range plots established using seedlings transplanted from soil containers at Tintic, Utah and Providence, Utah testing sites (Table S1). Germinated seedlings were planted into soil containers (4-cm diameter) in December, 2010 and then transplanted into a cultivated soil with dibbled holes in May, 2010 so that each plot was comprised of seven plants in a row, with $1 \mathrm{~m}$ between plants and $1 \mathrm{~m}$ between rows for a total plot size of $7 \mathrm{~m}^{2}\left(1 \mathrm{plant} \cdot \mathrm{m}^{-2}\right)$. Plots were replicated in a randomized complete block (RCB) design with six replications at each testing site. Plots were maintained with light cultivation to remove weeds as needed, with no fertilizer or irrigation. Once established, these plots have plant densities similar to typical natural stands of BWR in its native range environments. The plots were harvested to a height of $8 \mathrm{~cm}$ and weighed using a Swift Forage Harvester (Swift Machine and Welding LTD, Swift Current, Saskatchewan, Canada) once each year on 9 August 2011 and 28 August 2012 at the Providence site and 25 August 2011 and 29 August 2012 at the Tintic site. Results were reported on a DMY per unit area basis $\left(\mathrm{Mg} \cdot \mathrm{ha}^{-1}\right)$. Subsamples of harvested plant material were weighed, at the time of harvest, and dried at $60^{\circ} \mathrm{C}$ in a forced-air oven to constant weights that were used to convert fresh harvest weights to DMY.

Prior to development of the half-sib hybrids, biomass yields of two single-cross 4X Acc:641 CWR $\times 4$ X Acc:636 BWR hybrid genets-TC1 and TC2-were also evaluated relative to the 4X Acc:641.T CWR genet, 4X Acc:641 CWR population, 4X Acc:636 ,'Magnar' BWR, 'Continental' BWR, 'Trailhead' BWR, 'Rio' CWR, 'Mustang' Altai wildrye, 'Alkar' tall wheatgrass, and four varieties of switchgrass ('Alamo', 'Dacotah', 'Falcon', and 'Sunburst') in space-planted dryland range plots over four years (2008-2011) and two locations near Hyde Park, Utah and Tetonia, Idaho (Table S1). The management of the experiments conducted at the Hyde Park and Tetonia sites was similar to the dryland range evaluations at the Providence and Tintic sites, except that plants were spaced $0.5 \mathrm{~m}$ within rows [14] and cultivated at least once each year, deeply, to maintain separation between highly rhizomatous plots containing CWR and CWR backcross lines [14].

\subsection{Evaluation of Biomass-Related Traits in an Irrigated Production System}

Dry matter yield BWR, CWR $\times$ BWR half-sib hybrid populations, and other large-statured perennial grasses were evaluated in a two-harvest irrigated production system over four years at the Western Colorado Research Center located in the Grand Valley of the Colorado River near Fruita (Table S1).

A seedbed was prepared for furrow irrigation using equipment commonly used in Grand Valley region, which resulted in a smooth, flat-bed surface with V-shaped furrows approximately $10-\mathrm{cm}$ deep with 76-cm space between the bottom of each furrow. The experiment was planted on 20 October 2011 using a cone plot planter. Two seed rows were sown about $2-\mathrm{cm}$ deep with $30-\mathrm{cm}$ spacing within each bed and about $46-\mathrm{cm}$ spacing between beds. The plot size was $3.05 \mathrm{~m}$ wide (four seed beds with a total of eight seed rows) and $4.57 \mathrm{~m}$ long for a total area of $13.94 \mathrm{~m}^{2}$. The soil was a Glenton very fine sandy loam (coarse-loamy, mixed (calcareous), mesic family of Typic Torrifluvents). The plot area was soil sampled prior to planting, which was performed on 20 October 2011. The results of the soil test analysis were: $\mathrm{pH} 7.7,0.4 \mathrm{mmhos} / \mathrm{cm}, 1.4 \%$ organic matter, 8 ppm $\mathrm{NO}_{3}-\mathrm{N}, 13 \mathrm{ppm} \mathrm{P}$, and $62 \mathrm{ppm} \mathrm{K}$.

This experiment included two CWR $\times$ BWR half-sib hybrid populations plus selected reference populations of Altai wildrye (Leymus angustus); intermediate wheatgrass (Thinopyrum intermedium), switchgrass (Panicum virgatum), tall wheatgrass (Thinopyrum intermedium), and two species mixtures. 'Mustang' Altai wildrye; four BWR populations 4X Acc:636, 8X 'Continental', 8X 'Magnar', and 4X 'Trailhead'; 'Oahe' and 'Rush' intermediate wheatgrass; 'Alkar' tall wheatgrass; and two CWR $\times$ BWR half-sib hybrid populations were all seeded at a rate of $16.8 \mathrm{~kg} \cdot \mathrm{ha}^{-1}$ for each population in each plot. 
A switchgrass variety mixture, comprised of cultivars 'Blackwell' and 'Dacotah', was seeded at rates of $3.36 \mathrm{~kg} \cdot \mathrm{ha}^{-1}$ for each variety with an overall seeding rate of $6.72 \mathrm{~kg} \cdot \mathrm{ha}^{-1}$.

Plots were harvested twice each year, over a period of four years, with an automated forage plot harvester [59]. In the first harvest year of 2012, while plants were in the juvenile phase of development, plots were harvested on 24 July and 11 October with an application of $56 \mathrm{~kg} \mathrm{~N} \mathrm{ha}^{-1}$ on $27 \mathrm{July}$. In the second harvest year of 2013, plots were harvested on 20 June and 22 October with an application of $56 \mathrm{~kg} \mathrm{~N} \mathrm{ha}^{-1}$ on 24 June. In the third harvest year of 2014, plots were harvested on 19 June and 9 October, with an application of $56 \mathrm{~kg} \mathrm{~N} \mathrm{ha}^{-1}+122 \mathrm{~kg} \mathrm{P}_{2} \mathrm{O}_{5} \mathrm{ha}^{-1}$ on 20 June. In the fourth harvest year of 2015, plots were harvested on 19 June and 8 October, with applications of $56 \mathrm{~kg} \mathrm{~N} \mathrm{ha}^{-1}$ on 10 April and $56 \mathrm{~kg} \mathrm{~N} \mathrm{ha}^{-1}+40 \mathrm{~kg} \mathrm{P}_{2} \mathrm{O}_{5} \mathrm{ha}^{-1}+13 \mathrm{~kg} \mathrm{~K}_{2} \mathrm{O}^{-1}$ on 21 June. During harvest, a small forage sample was obtained from each plot and oven-dried at $50{ }^{\circ} \mathrm{C}$ to a constant weight that was used to convert fresh weight yields to DMY. The experiment was furrow-irrigated each year with irrigation water from the Colorado River delivered through a canal system. No herbicides were applied at any time to the plots during the study.

\subsection{Statistical Analysis of Trait Data}

Field trait data were analyzed within and among years and locations using the MIXED procedure of SAS version 9.4 with the repeated option to model covariance structure between years (SAS Institute, Cary, North Carolina, USA). Population, years, and locations were assumed to be fixed effects with replications as random effects. Mean comparisons were made among populations using Fisher Protected Least Significant Difference tests at the $p=0.05$ level of probability.

\section{Conclusions}

This study demonstrated a useful approach to produce hybrid seed for allogamous perennial grasses, which has been a long-standing problem in perennial grass improvement. Our study also provided new information on the biomass yield accumulation potential of BWR and other cool-season grasses in a two-harvest irrigated production system in a high-elevation, cold-desert environment of the western United States. Performance of BWR and other grasses in a two-harvest irrigated production system demonstrated significant regrowth potential of native grasses such as BWR. Comparisons of relative biomass yields across a wide range of irrigated and dryland environments of western North America, including new testing sites utilized in this study, indicate that cool-season grasses may have significant advantages over switchgrass under non-irrigated or limited-irrigation systems in this region. Although tall wheatgrass was clearly the best yielding population in this irrigated testing environment, BWR and CWR $\times$ BWR hybrids performed as good as or better than tall wheatgrass and other introduced species in the dryland range environments. Results the two-harvest irrigated field experiment demonstrated that switchgrass can also do well in a cold-desert environment if irrigation supplies are sufficient throughout the entire growing season. However, development and testing of cool-season perennial grass species, hybrids, and varieties across a wide range of growing environments is needed to expand the range of adaptation of grasses used for low-input bioenergy and forage production in the western United States and other parts of North America. Although biomass yields of BWR and other perennial grasses varied greatly over different environments, we detected significant genetic variation for this trait across widely various conditions. Some hybrids of CWR $\times$ BWR exhibited indications of mid- or high-parent heterosis and there were very large differences between the biomass yields obtained using a small sample of only two different CWR genets as seed parents and two BWR populations as pollen parents. Future efforts to develop CWR $\times$ BWR hybrids should focus on the identification and utilization of superior CWR genets as half-sib hybrid seed parents in addition to superior BWR pollen parents.

Supplementary Materials: The following are available online at www.mdpi.com/2073-4395/7/1/3/s1. 
Author Contributions: "S.R.L., C.H.P., K.B.J., and I.W.M. conceived and designed experiments; T.A.J. developed the TC1 and TC2 $\mathrm{F}_{1}$ hybrids and the interploidy hybrid 'Continental'; S.R.L., M.D.R., and B.L.W. analyzed data; S.R.L. and J.E.S. wrote the paper." All authors read and approved the paper.

Conflicts of Interest: The authors declare no conflict of interest.

\section{References}

1. Lewandowski, I.; Scurlock, J.M.O.; Lindvall, E.; Christou, M. The development and current status of perennial rhizomatous grasses as energy crops in the U.S. and Europe. Biomass Bioenergy 2003, 25, 335-361. [CrossRef]

2. McLaughlin, S.B.; Kszos, L.A. Development of switchgrass (Panicum virgatum) as a bioenergy feedstock in the United States. Biomass Bioenergy 2005, 28, 515-535. [CrossRef]

3. Parrish, D.J.; Fike, J.H. The biology and agronomy of switchgrass for biofuels. Crit. Rev. Plant Sci. 2005, 24, 423-459. [CrossRef]

4. Wright, L.; Turhollow, A. Switchgrass selection as a "model" bioenergy crop: A history of the process. Biomass Bioenergy 2010, 34, 851-868. [CrossRef]

5. Casler, M.D.; Vogel, K.P.; Harrison, M. Switchgrass germplasm resources. Crop Sci. 2015, 55, $2463-2478$. [CrossRef]

6. Monono, E.M.; Nyren, P.E.; Berti, M.T.; Pryor, S.W. Variability in biomass yield, chemical composition, and ethanol potential of individual and mixed herbaceous biomass species grown in North Dakota. Ind. Crops Prod. 2013, 41, 331-339. [CrossRef]

7. Wang, G.J.; Nyren, P.; Xue, Q.W.; Aberle, E.; Eriksmoen, E.; Tjelde, T.; Liebig, M.; Nichols, K.; Nyren, A. Establishment and yield of perennial grass monocultures and binary mixtures for bioenergy in North Dakota. Agron. J. 2014, 106, 1605-1613. [CrossRef]

8. Lee, D.; Owens, V.N.; Boe, A.; Koo, B.C. Biomass and seed yields of big bluestem, switchgrass, and intermediate wheatgrass in response to manure and harvest timing at two topographic positions. CB Bioenergy 2009, 1, 171-179. [CrossRef]

9. Harmoney, K.R. Cool-season grass biomass in the southern mixed-grass prairie region of the USA. Bioenergy Res. 2015, 8, 203-210. [CrossRef]

10. Jefferson, P.G.; McCaughey, W.P.; May, K.; Wosaree, J.; MacFarlane, L.; Wright, S.M.B. Performance of American native grass cultivars in the Canadian Prairie Provinces. Nativ. Plants J. 2002, 3, 24-33. [CrossRef]

11. Robins, J.G. Cool-season grasses produce more total biomass across the growing season than do warm-season grasses when managed with an applied irrigation gradient. Biomass Bioenergy 2010, 34, 500-505. [CrossRef]

12. Porensky, L.M.; Davison, J.; Leger, E.A.; Miller, W.W.; Goergen, E.M.; Espeland, E.K.; Carroll-Moore, E.M. Grasses for biofuels: A low water-use alternative for cold desert agriculture? Biomass Bioenergy 2014, 66, 133-142. [CrossRef]

13. Pearson, C.H.; Larson, S.R.; Keske, C.M.H.; Jensen, K.B. Native grasss for biomass production at high elevations. In Industrial Crops: Breeding for Bioenergy and Bioproducts; Cruz, M.V., Dierig, D.A., Eds.; Springer: New York, NY, USA, 2015; pp. 101-132.

14. Larson, S.R.; Jensen, K.B.; Robins, J.G.; Waldron, B.L. Genes and quantitative trait loci controlling biomass yield and forage quality traits in perennial wildrye. Crop Sci. 2014, 54, 111-126. [CrossRef]

15. Aguirre, A.A.; Studer, B.; Frei, U.; Lubberstedt, T. Prospects for hybrid breeding in bioenergy grasses. Bioenergy Res. 2012, 5, 10-19. [CrossRef]

16. Heaton, E.A.; Dohleman, F.G.; Miguez, A.F.; Juvik, J.A.; Lozovaya, V.; Widholm, J.; Zabotina, O.A.; Mcisaac, G.F.; David, M.B.; Voigt, T.B.; et al. Miscanthus: A promising biomass crop. Adv. Bot. Res. 2010, 56, 75-137.

17. Linde-Laursen, I. Cytogenetic analysis of Miscanthus 'Giganteus', an interspecific hybrid. Hereditas 1993, 119, 297-300. [CrossRef]

18. Hodkinson, T.R.; Chase, M.W.; Takahashi, C.; Leitch, I.J.; Bennett, M.D.; Renvoize, S.A. The use of DNA sequencing (ITS and trnl-f), AFLP, and fluorescent in situ hybridization to study allopolyploid Miscanthus (Poaceae). Am. J. Bot. 2002, 89, 279-286. [CrossRef] [PubMed]

19. Yamada, T. Miscanthus. In Industrial Crops: Breeding for Bioenergy and Bioproducts; Cruz, M.V., Dierig, D.A., Eds.; Springer: New York, NY, USA, 2015; pp. 43-66. 
20. Robson, P.; Jensen, E.; Hawkins, S.; White, S.R.; Kenobi, K.; Clifton-Brown, J.; Donnison, I.; Farrar, K. Accelerating the domestication of a bioenergy crop: Identifying and modelling morphological targets for sustainable yield increase in Miscanthus. J. Exp. Bot. 2013, 64, 4143-4155. [CrossRef] [PubMed]

21. Nishiwaki, A.; Mizuguti, A.; Kuwabara, S.; Toma, Y.; Ishigaki, G.; Miyashita, T.; Yamada, T.; Matuura, H.; Yamaguchi, S.; Rayburn, A.L.; et al. Discovery of natural Miscanthus (Poaceae) triploid plants in sympatric populations of Miscanthus sacchariflorus and Miscanthus sinensis in southern Japan. Am. J. Bot. 2011, 98, 154-159. [CrossRef] [PubMed]

22. Dwiyanti, M.S.; Rudolph, A.; Swaminathan, K.; Nishiwaki, A.; Shimono, Y.; Kuwabara, S.; Matuura, H.; Nadir, M.; Moose, S.; Stewart, J.R.; et al. Genetic analysis of putative triploid Miscanthus hybrids and tetraploid M. sacchariflorus collected from sympatric populations of Kushima, Japan. Bioenergy Res. 2013, 6, 486-493. [CrossRef]

23. Tamura, K.; Sanada, Y.; Shoji, A.; Okumura, K.; Uwatoko, N.; Anzoua, K.G.; Sacks, E.J.; Yamada, T. DNA markers for identifying interspecific hybrids between Miscanthus sacchariflorus and Miscanthus sinensis. Grassl. Sci. 2015, 61, 160-166. [CrossRef]

24. Hodkinson, T.R.; Klaas, M.; Jones, M.B.; Prickett, R.; Barth, S. Miscanthus: A case study for the utilization of natural genetic variation. Plant Genet. Resour. C 2015, 13, 219-237. [CrossRef]

25. Martinez-Reyna, J.M.; Vogel, K.P. Heterosis in switchgrass: Spaced plants. Crop Sci. 2008, 48, $1312-1320$. [CrossRef]

26. Vogel, K.P.; Mitchell, K.B. Heterosis in switchgrass: Biomass yield in swards. Crop Sci. 2008, 48, $2159-2164$. [CrossRef]

27. Casler, M.D. Heterosis and reciprocal-cross effects in tetraploid switchgrass. Crop Sci. 2014, 54, $2063-2069$. [CrossRef]

28. Casler, M.D.; Vogel, K.P. Selection for biomass yield in upland, lowland, and hybrid switchgrass. Crop Sci. 2014, 54, 626-636. [CrossRef]

29. Zalapa, J.E.; Price, D.L.; Kaeppler, S.M.; Tobias, C.M.; Okada, M.; Casler, M.D. Hierarchical classification of switchgrass genotypes using SSR and chloroplast sequences: Ecotypes, ploidies, gene pools, and cultivars. Theor. Appl. Genet. 2011, 122, 805-817. [CrossRef] [PubMed]

30. Lu, F.; Lipka, A.E.; Glaubitz, J.; Elshire, R.; Cherney, J.H.; Casler, M.D.; Buckler, E.S.; Costich, D.E. Switchgrass genomic diversity, ploidy, and evolution: Novel insights from a network-based SNP discovery protocol. PLoS Genet. 2013, 9, 139-147. [CrossRef] [PubMed]

31. Larson, S.R.; Wu, X.L.; Jones, T.A.; Jensen, K.B.; Chatterton, N.J.; Waldron, B.L.; Robins, J.G.; Bushman, B.S.; Palazzo, A.J. Comparative mapping of growth habit, plant height, and flowering QTLs in two interspecific families of Leymus. Crop Sci. 2006, 46, 2526-2539. [CrossRef]

32. Reynolds, T.D.; Fraley, L. Root profiles of some native and exotic plant-species in southeastern Idaho. Environ. Exp. Bot. 1989, 29, 241-248. [CrossRef]

33. Culumber, C.M.; Larson, S.R.; Jensen, K.B.; Jones, T.A. Genetic structure of Eurasian and North American Leymus (Triticeae) wildryes assessed by chloroplast DNA sequences and AFLP profiles. Plant Syst. Evol. 2011, 294, 207-225. [CrossRef]

34. Johnson, R.; Vance-Borland, K. Linking genetic variation in adaptive plant traits to climate in tetraploid and octoploid basin wildrye [Leymus cinereus (Scribn. \& Merr.) a. Love] in the western U.S. PLoS ONE 2016, 11, e0148982.

35. Jones, T.A.; Parr, S.D.; Winslow, S.R.; Rosales, M.A. Notice of release of 'Continental' basin wildrye. Nativ. Plants J. 2009, 10, 57-61. [CrossRef]

36. USDA-NRCS. Conservation Plant Release Brochure for 'Rio' Beardless Wild Rye (Leymus triticoides Buckley); United States Department of Agriculture, Natural Resources Conservation Service, California Plant Materials Center: Lockeford, CA, USA, 2014.

37. Suyama, H.; Benes, S.E.; Robinson, P.H.; Getachew, G.; Grattan, S.R.; Grieve, C.M. Biomass yield and nutritional quality of forage species under long-term irrigation with saline-sodic drainage water: Field evaluation. Anim. Feed Sci. Technol. 2007, 135, 329-345. [CrossRef]

38. Benes, S.E.; Adhikari, D.D.; Grattan, S.R.; Snyder, R.L. Evapotranspiration potential of forages irrigated with saline-sodic drainage water. Agric. Water Manag. 2012, 105, 1-7. [CrossRef] 
39. Yun, L.; Larson, S.R.; Mott, I.W.; Jensen, K.B.; Staub, J.E. Genetic control of rhizomes and genomic localization of a major-effect growth habit QTL in perennial wildrye. Mol. Genet. Genom. 2014, 289, 383-397. [CrossRef] [PubMed]

40. Martinez-Reyna, J.M.; Vogel, K.P.; Caha, C.; Lee, D.J. Meiotic stability, chloroplast DNA polymorphisms, and morphological traits of upland $\times$ lowland switchgrass reciprocal hybrids. Crop Sci. 2001, 41, 1579-1583. [CrossRef]

41. Johnston, S.A.; Dennijs, T.P.M.; Peloquin, S.J.; Hanneman, R.E. The significance of genic balance to endosperm development in interspecific crosses. Theor. Appl. Genet. 1980, 57, 5-9. [CrossRef] [PubMed]

42. USDA-NRCS. Notice of Release of 'Rio' Beardless Widlrye; USDA-Natural Resources Conservation Service: Lockeford, CA, USA, 1991.

43. Brummer, E.C. Capturing heterosis in forage crop cultivar development. Crop Sci. 1999, 39, $943-954$. [CrossRef]

44. Knowles, R.P. Comparison of cultivar hybrids and blends with pure cultivars in crested wheatgrass. Can. J. Plant Sci. 1979, 59, 1019-1023. [CrossRef]

45. Foster, C.A. Interpopulational and intervarietal hybridization in Lolium perenne breeding: Heterosis under non-competitive conditions. J. Agric. Sci. 1971, 76, 107-130. [CrossRef]

46. Foster, C.A. Interpopulational and intervarietal F1 hybrids in Lolium perenne: Performance in field sward conditions. J. Agric. Sci. 1973, 80, 463-477. [CrossRef]

47. Lemeziene, N.; Norkeviciene, E.; Liatukas, Z.; Dabkeviciene, G.; Ceceviciene, J.; Butkute, B. Switchgrass from North Dakota - an adaptable and promising energy crop for northern regions of Europe. Acta Agric. Scand. 2015, 65, 118-124.

48. Sage, R.F.; Peixoto, M.D.; Friesen, P.; Deen, B. C-4 bioenergy crops for cool climates, with special emphasis on perennial c-4 grasses. J. Exp. Bot. 2015, 66, 4195-4212. [CrossRef] [PubMed]

49. Cash, S.D.; Majerus, M.E.; Scheetz, J.C.; Holzworth, L.K.; Murphy, C.L.; Wichman, D.M.; Bowman, H.F.; Ditterline, R.L. Registration of 'Trailhead' basin wildrye. Crop Sci. 1998, 38, 278. [CrossRef]

50. Alderson, J.S.; Sharp, W.C.; Hanson, A.A.; U.S. Department of Agriculture. Grass Varieties in the United States; CRC Lewis Publishers: Boca Raton, FL, USA, 1995.

51. Wu, X.L.; Larson, S.R.; Hu, Z.M.; Palazzo, A.J.; Jones, T.A.; Wang, R.R.C.; Jensen, K.B.; Chatterton, N.J. Molecular genetic linkage maps for allotetraploid Leymus wildryes (Gramineae:Triticeae). Genome 2003, 46, 627-646. [CrossRef] [PubMed]

52. Jensen, K.B.; Zhang, Y.F.; Dewey, D.R. Mode of pollination of perennial species of the Triticeae in relation to genomically defined genera. Can. J. Plant Sci. 1990, 70, 215-225. [CrossRef]

53. PRISM Climate Group. Oregon State University. Available online: http://prism.oregonstate.edu (accessed on 23 December 2016).

54. Utah Climate Center, Utah State University. Available online: https://climate.usurf.usu.edu (accessed on 23 December 2016).

55. Vos, P.; Hogers, R.; Bleeker, M.; Reijans, M.; van de Lee, T.; Hornes, M.; Frijters, A.; Pot, J.; Peleman, J.; Kuiper, M.; et al. AFLP: A new technique for DNA fingerprinting. Nucleic Acids Res. 1995, 23, 4407-4414. [CrossRef] [PubMed]

56. Falush, D.; Stephens, M.; Pritchard, J.K. Inference of population structure using multilocus genotype data: Dominant markers and null alleles. Mol. Ecol. Notes 2007, 7, 574-578. [CrossRef] [PubMed]

57. Pritchard, J.K.; Stephens, M.; Donnelly, P. Inference of population structure using multilocus genotype data. Genetics 2000, 155, 945-959. [PubMed]

58. Leonard, A.C.; Franson, S.E.; Hertzberg, V.S.; Smith, M.K.; Toth, G.P. Hypothesis testing with the similarity index. Mol. Ecol. 1999, 8, 2105-2114. [CrossRef] [PubMed]

59. Pearson, C.H. An updated, automated commercial swather for harvesting forage plots. Agron. J. 2007, 99, 1382-1388. [CrossRef]

(c) 2017 by the authors; licensee MDPI, Basel, Switzerland. This article is an open access article distributed under the terms and conditions of the Creative Commons Attribution (CC-BY) license (http://creativecommons.org/licenses/by/4.0/). 